DAvid A. ANDERSON†

TABLE OF CONTENTS

INTRODUCTION .................... 488

I. The Constitutional LAW of Defamation . . . . . . 493

A. Actual Malice . . . . . . . . . . . . . . . . . 493

B. Convincing Clarity . . . . . . . . . . . . . . 494

C. Independent Review . . . . . . . . . . . . 495

D. Summary Judgment . . . . . . . . . . . . 498

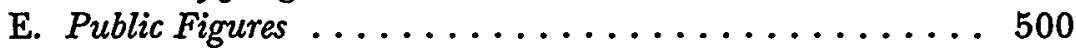

F. Private Plaintiffs . ................ 501

G. Neutral Reportage . . . . . . . . . . . . . 503

H. Falsity . . . . . . . . . . . . . . . . 504

I. Nonfactual Expressions . . . . . . . . . . . 505

J. What Remains Is Not a General Remedy for Defamation . . 509

II. The Residual REMEdY $\ldots \ldots \ldots \ldots \ldots \ldots \ldots \ldots$

A. Protracted Litigation $\ldots \ldots \ldots \ldots \ldots \ldots \ldots \ldots \ldots$

B. Uncontrolled Damages . . . . . . . . . . . . . 513

C. Intrusion into Editorial Processes ........... 516

D. Diverting the Inquiry Away from Truth . . . . . . 521

E. Prejudicing Defendants ................ 522

III. The RePutational AND Social Costs . . . . . . . 524

A. Reputational Costs . . . . . . . . . . . . 524

B. Social Costs ..................... 531

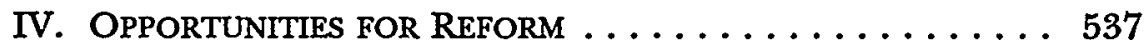

A. Reconsidering the Constitutional Law ... . . . . 537

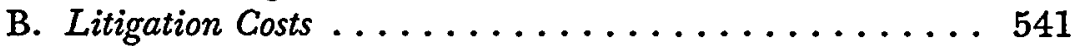

C. Politics of Reform .................. 546

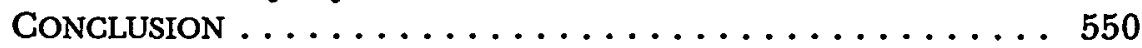

† Thompson \& Knight Centennial Professor, University of Texas Law School. Earlier versions of this essay were read by my colleagues, L.A. Powe, Jr. and Cynthia Estlund; Professor Marc A. Franklin of Stanford; and three knowledgeable libel lawyers, P. Cameron DeVore, Marshall Nelson, and Bruce Johnson. With varying degrees of violence, all disagreed with some of the ideas and none should be thought to have endorsed my conclusions. Nonetheless, I benefitted greatly from the suggestions of each. I am indebted to Ellen Williams and Howard Lidsky for their research assistance. 


\section{INTRODUCTION}

The remnants of American libel law provide little protection for reputation. The actual malice rule of New York Times $v$. Sullivan ${ }^{1}$ does not adequately protect the press, so courts have imposed many other constitutional limitations on the libel action. ${ }^{2}$ Cumulatively, these make the remedy largely illusory. Most victims of defamation cannot meet the actual malice requirement and many who can are thwarted by other constitutional obstacles.

Nonetheless, libel law continues to exact a price from speech. The constitutional protections are designed to, and often do, encourage the media to defame. Outraged juries frequently return six- or seven-figure verdicts. Although such verdicts are usually reversed on appeal, defamation victims continue to sue. While the likelihood of success is minuscule, the amount at issue is usually large, so the media defend vigorously. Because many of the constitutional issues do not lend themselves to preliminary disposition, even the least meritorious cases can require extensive discovery on both sides. Those actions that go to trial often produce plaintiffs' judgments that are eventually reversed on constitutional grounds. Libel law, as modified over the past twentyfive years, produces expensive litigation and occasional large judgments, and therefore continues to chill speech. ${ }^{3}$

I 376 U.S. 254 (1964).

2 The Supreme Court has decided 27 libel cases since New York Times v. Sullivan. They are cited here chronologically: Garrison v. Louisiana, 379 U.S. 64 (1964); Henry v. Collins, 380 U.S. 356 (1965); Linn v. United Plant Guard Workers, 383 U.S. 53 (1966); Rosenblatt v. Baer, 383 U.S. 75 (1966); Curtis Publishing Co. v. Butts, 388 U.S. 130 (1967); Beckley Newspapers Corp. v. Hanks, 389 U.S. 81 (1967); St. Amant v. Thompson, 390 U.S. 727 (1968); Greenbelt Coop. Publishing Ass'n v. Bresler, 398 U.S. 6 (1970); Monitor Patriot Co. v. Roy, 401 U.S. 265 (1971); Time, Inc. v. Pape, 401 U.S. 279 (1971); Ocala Star-Banner Co. v. Damron, 401 U.S. 295 (1971); Rosenbloom v. Metromedia, Inc., 403 U.S. 29 (1971); Old Dominion Branch No. 496, National Ass'n of Letter Carriers v. Austin, 418 U.S. 264 (1974); Gertz v. Robert Welch, Inc., 418 U.S. 323 (1974); Time, Inc. v. Firestone, 424 U.S. 448 (1976); Herbert v. Lando, 441 U.S. 153 (1979); Hutchinson v. Proxmire, 443 U.S. 111 (1979); Wolston v. Reader's Digest Ass'n, 443 U.S. 157 (1979); Keeton v. Hustler Magazine, 465 U.S. 770 (1984); Calder v. Jones, 465 U.S. 783 (1984); Bose Corp. v. Consumers Union, 466 U.S. 485 (1984); Dun \& Bradstreet, Inc. v. Greenmoss Builders, 472 U.S. 749 (1985); Philadelphia Newspapers, v. Hepps, 475 U.S. 767 (1986); Anderson v. Liberty Lobby, Inc., 477 U.S. 242 (1986); Harte-Hanks Communications v. Connaughton, 491 U.S. 657 (1989); Milkovich v. Lorain Journal Co., 110 S. Ct. 2695 (1990); Masson v. New Yorker Magazine, Inc., 111 S. Ct. 2419 (1991).

${ }^{3}$ Scholarly and popular criticism of libel law is voluminous. See Randall P. BEZANSON ET AL., LIBEL LAW AND THE PRESS: MYTH AND REALITY (1987) [hereinafter Libel LAW AND THE PREss]; LoIs G. ForeR, A CHLlling EFfect: THE MOUNTING 
As it stands today, libel law is not worth saving. What we have is a system in which most claims are judicially foreclosed after costly litigation. It gives plaintiffs delusions of large windfalls, defendants nightmares of intrusive and protracted litigation, and the public little assurance that the law favors truth over falsehood. If we can do no better, honesty and efficiency demand that we abolish the law of libel.

Threat of LIBEL AND INVASION OF PRIVACy ACTIONS TO THE FIRST AMENDMENT (1987); W. WAT HOPKINS, ACTUAL MALICE: TWENTY-FTVE YEARS AFTER TIMES V. SUllivaN (1989); ANTHONY LeWIS, MAKE No LAW: THE SullivaN CASE AND THE FIRST AMENDMENT (1991) [hereinafter MAKE NO LAW]; LUCAS A. POWE, JR., THE FOURTH ESTATE AND THE CONSTITUTION: FREEDOM OF THE PRESS IN AMERICA (1991); RODNEY A. SMOLLA, SUING THE PRESS (1986) [hereinafter SMOLIA, SUING]; WILLIAM TAVOULAREAS, FIGHTING BACK (1985). The most important articles include Jerome A. Barron, The Search for Media Accountability, 19 SUFFOLK U. L. REV. 789 (1985); Randall P. Bezanson, The Libel Tort Today, 45 WASH. \& LEE L. REV. 535 (1988) [hereinafter Libel Tort Today]; Randall Bezanson \& Brian C. Murchison, The Three Voices of Libel, 47 WASH. \& LEE L. REV. 213 (1990) [hereinafter Three Voices]; David Elder, Defamation, Public Officialdom and the Rosenblatt v. Baer Criteria-A Proposal for Revivification: Two Decades After New York Times Co.v. Sullivan, 33 BuFF. L. REv. 579 (1985); Jonathan L. Entin, Privacy, Emotional Distress, and the Limits of Libel Law Reform, 38 MERCER L. REV. 835 (1987); Richard A. Epstein, Was New York Times v. Sullivan Wrong?, 53 U. CHI. L. Rev. 782 (1986); Marc A. Franklin, Good Names and Bad Law: A Critique of Libel Law and a Proposal, 18 U.S.F. L. REv. 1 (1983); Marc A. Franklin \& Daniel J. Bussel, The Plaintiff's Burden in Defamation: Awareness and Falsity, 25 WM. \& MARY L. REV. 825 (1984); Sheldon W. Halpern, Values and Value: An Essay on Libel Reform, 47 WASH. \& LEE L. REV. 227 (1990); Stanley Ingber, Defamation: $A$ Conflict Between Reason and Decency, 65 VA. L. Rev. 785 (1979); Anthony Lewis, New York Times v. Sullivan Reconsidered: Time to Return to "The Central Meaning of the First Amendment," 83 Colum. L. REv. 603 (1983) [hereinafter Lewis, New York Times v. Sullivan Reconsidered]; Michael Massing, The Libel Chill: How Cold is it Out There?, Colum. JournalisM REV., May/June 1985, at 31; Robert C. Post, The Social Foundations of Defamation Law: Reputation and the Constitution, 74 CAL. L. REv. 691 (1986); Frederick Schauer, Public Figures, 25 WM. \& MARY L. REV. 905 (1984); Gordon Schneider, A Model for Relating Defamatory “Opinions" to First Amendment Protected "Ideas," 43 ARK. L. REV. 57 (1990); Rodney A. Smolla, Dun \& Bradstreet, Hepps and Liberty Lobby: A New Analytic Primer on the Future Course of Defamation, 75 GEO. L.J. 1519 (1987); Rodney A. Smolla, Let the Author Beware: The Rejuvenation of the American Law of Libel, 132 U. PA. L. REV. 1 (1983) [hereinafter Smolla, Let the Author Beware]; Rodney A. Smolla \& Michael J. Gaertner, The Annenberg Libel Reform Proposal: The Case for Enactment, 31 WM. \& MARY L. REV. 25 (1989); William W. Van Alstyne, First Amendment Limitations on Recovery from the Press-An Extended Comment on "The Anderson Solution," 25 WM. \& MARY L. REV. 793 (1984); Diane L. Zimmerman, Curbing the High Price of Loose Talk, 18 U.C. DAVIS L. REV. 359 (1985); see also David A. Anderson, Reputation, Compensation, and Proof, 25 WM. \& MARY L. REV. 747 (1984); Floyd Abrams, Why We Should Change the Libel Law, N.Y. TimES, Sept. 29, 1985, § 6 (Magazine), at 34.

The articles cited in note 5 , infra, proposing various reforms, also contain much criticism of existing libel law. 
Much can be said for that course. Since our forebears abandoned licensing, libel has been the principal legal threat to freedom of the press. Abolishing libel law is the only way to completely eliminate the chilling effect that it exerts on the press. To paraphrase Judge Edgerton, whatever is subtracted from the field of libel is added to the field of free debate. ${ }^{4}$ Abolition would leave victims of defamation little worse off than they are today. A few would give up recoveries, but many would be spared the costs, emotional as well as financial, of hopeless litigation. The public would get the benefit of information that is now suppressed by the chill of libel law, and would be disabused of the inferences that may be drawn from a mistaken belief that defamatory falsehoods are generally actionable.

No matter how much it values speech, however, a civilized society cannot refuse to protect reputation. Some form of libel law is as essential to the health of the commonweal and the press as it is to the victims of defamation. Without libel law, credibility of the press would be at the mercy of the least scrupulous among it, and public discourse would have no necessary anchor in truth.

From the point of view of the defamed, the defamers, or the public, the law of libel is obviously ripe for reform. Many proposals have been offered over the past decade, ${ }^{5}$ but so far all have been

${ }^{4}$ See Sweeney v. Patterson, 128 F.2d 457, 458, cert. denied, 317 U.S. 678 (1942) ("Whatever is added to the field of libel is taken from the field of free debate."). Indeed, I argue that the present law takes even more from speech than it contributes to protecting reputation. See infra notes 206-09 and accompanying text.

${ }^{5}$ For the most widely discussed proposals, see H.R. 2846, 99th Cong., 1st Sess. (1985) (proposal by Congressman Charles Schumer); THE ANNENBERG WASHINGTON Program, Proposal for THE REForm OF LIBEL LAW (1988) [hereinafter ANNENBERG Proposal]; Policy Guide of the American Civil Liberties Union 11-13 (June 1989) (on file with the author) (policy no. 6, Libel and Invasions of Privacy Through Speech).

For other reform proposals, some comprehensive and some aimed at limited areas of libel law, see David A. Barrett, Declaratory Judgments for Libel: A Better Alternative, 74 CAL. L. REv. 847 (1986); Dale M. Cendali, Of Things to Come-The Actual Impact of Herbert v. Lando and a Proposed National Correction Statute, 22 HARV. J. ON LEGIS. 441 (1985); Geoffrey C. Cook, Reconciling the First Amendment with the Individual's Reputation: The Declaratory Judgment as an Option for Libel Suits, 93 DICK. L. REV. 265 (1989); C. Thomas Dienes, Libel Reform: An Appraisal, 23 U. MICH. J.L. REF. 1 (1989); Marc A. Franklin, A Declaratory Judgment Alternative to Current Libel Law, 74 CAL. L. REV. 809 (1986); Sheldon W. Halpern, Of Libel, Language, and Law: New York Times v. Sullivan at Twenty-Five, 68 N.C. L. REV. 273 (1990); James H. Hulme, Vindicating Reputation: An Alternative to Damages as a Remedy for Defamation, 30 AM. U. L. REv. 375 (1981); Stanley Ingber, Rethinking Intangible Injuries: A Focus on Remedy, 73 CAL. L. REV. 772 (1985); Paul A. LeBel, Reforming the Tort of Defamation: An Accommodation of the Competing Interests Within the Current Constitutional Framework, 66 NEb. L. REv. 249 (1987); Pierre N. Leval, The No-Money, No-Fault Libel Suit: 
stillborn because of opposition by the media bar ${ }^{6}$ and the absence of any organized support. Now, however, the reform movement has, if not a political constituency, at least an institutional protagonist. The National Conference of Commissioners on Uniform State Laws is preparing a proposed Uniform Defamation Act, to be voted on by the Conference in 1992. ${ }^{7}$ In the pattern of previous reform

Keeping Sullivan in its Proper Place, 101 HARv. L. REv. 1287 (1988).

${ }^{6}$ See, e.g., Dienes, supra note 5 , at 2 (noting that all libel reforms have faced $a$ hostile media response); Harry M. Johnston III \& Henry R. Kaufman, “Annenberg, Sullivan at Twenty-Five, and the Question of Libel Reform, " CoMMS. LAW., Winter 1989, at 3 (criticizing the proposals set forth in the Libel Reform Act, which include a broadened remedy of retraction and reply, declaratory judgments on the issue of truth or judgments on the issue of truth or falsity, and prior consent of both parties to authorize a suit for monetary damages).

${ }^{7}$ See UnIForm Defamation Act (Proposed Official Draft Oct. 10, 1991) [hereinafter PROPOSED DEFAMATION ACT].

The proposed act is intricate and must be read in full for a complete appreciation of its effects. It is subject to change before final adoption. As of this writing, however, its major reform provisions may be summarized as follows:

(1) A defendant who makes a sufficient retraction within 45 days of plaintiff's request (or service of process) is liable only for plaintiff's pecuniary losses to the time of retraction. See id. $\$ \S 13,12(b), 15$.

(2) Anytime up to trial, a defendant may avoid liability for all except pecuniary losses by offering to make a sufficient retraction and pay plaintiff's litigation expenses. See id. $\$ 9$.

(3) A plaintiff who elects to sue for vindication rather than damages need not prove fault or overcome conditional privileges to obtain a judicial declaration of falsity and an order requiring defendant to publish the declaration or pay plaintiff to do so, and may be awarded attorney's fees if defendant unreasonably refused to retract. See id. $\$ \S 2,5,7$.

(4) A defendant may be awarded attorney's fees from a plaintiff who brings a vindication action without basis. See id. $\$ 7($ a)(ii).

(5) A plaintiff may recover only for pecuniary loss or proved harm to reputation and emotional distress resulting therefrom, and may not recover presumed damages. See id. $\S 10$.

(6) A plaintiff who prevails in a damage action may recover attorney's fees by proving that defendant refused plaintiff's timely request for retraction, caused plaintiff pecuniary harm, and published with knowledge of falsity or reckless disregard for the truth. See id. \$14.

(7) Punitive damages may be recovered only upon clear and convincing proof that defendant published with knowledge of falsity and ill will toward plaintiff. See id. § 11 .

The proposal contains many less fundamental changes in existing libel law. Some of them are unquestionably salutary, such as a requirement that plaintiffs specifically identify in their requests for retractions and pleading the language or implication claimed to be defamatory, see id. $\$ 4(a)$, and provisions consolidating and rationalizing the many absolute and conditional privileges, see id. $\$ \S 16-18$.

This Article is not intended as a critique of the proposed uniform act. I single it out only because it is the current, and perhaps most credible, embodiment of the reform movement. 
proposals, the proposed uniform act (1) retains present constitutional restrictions on monetary recovery, (2) further restricts the availability of presumed and punitive damages, and (3) requires many defamation victims to accept alternative remedies, namely retraction or a declaratory judgment of falsity, in lieu of damages.

Like its predecessors, this approach to reform is too modest. Instead of correcting the evils of the present libel law, it seeks to circumvent them through alternative remedies that are likely to prove ineffective. If libel law is to be worth saving, it must provide not merely nominal remedies, but remedies that protect reputation effectively, at the least possible cost to speech. Vindicatory declarations and other alternative remedies could supplement an effective and efficient system of libel law. But because of the realities of financing litigation against the legal and financial might of the media, monetary awards must continue to be the primary remedy. The principal opportunities for reform lie in abandoning some shibboleths about jury trials and in reducing the scale of libel litigation.

My objective in this Article is to show how the current law of libel affects the media, the victims of defamation, and the public, and how it might be changed. To appreciate these matters, one must come to grips with some arcana that is stock-in-trade to the libel bar but is little known to others. To understand that the constitutional law of libel is a rule requiring public officials and public figures to prove actual malice, or even that it is a system of fault-based rules that vary for different classes of cases, is to have an illusion of understanding. The constitutional law of libel has evolved far beyond the well-known fault requirements. The "actual malice" rule of New York Times $v$. Sullivan has been subsumed into an intricate complex of substantive, procedural, and evidentiary rules, some of which have little to do with "actual malice" and much to do with judicial power to reject jury findings. Virtually all libel litigation is now governed by the strictest constitutional limitations, rules conceived for libel suits by public officials. The perception that the actual malice regime is an exceptional one, applying only to a few libel plaintiffs, is a myth. Because of expansive definitions of public official and public figure, and because financial realities compel even private plaintiffs to seek presumed and punitive damages, the actual malice standard, with all its ancillary restrictions, is the rule rather than the exception. Part I explains how little protection of reputation remains under this system. 
Understanding how these rules work in litigation is essential to understanding why they fail to adequately protect freedom of speech (the subject of Part II), and why they exact too great a sacrifice of the individual and societal interests in reputation (the subject of Part III). Part IV discusses the directions reform might take and the obstacles it faces. I conclude that only the Supreme Court can bring about the reform of libel law.

\section{The Constitutional LaW of Defamation}

\section{A. Actual Malice}

The rule created by New York Times $v$. Sullivan, ${ }^{8}$ still the cornerstone of constitutional defamation law today, is that the First Amendment "prohibits a public official from recovering damages for a defamatory falsehood relating to his official conduct unless he proves that the statement was made with 'actual malice'-that is, with knowledge that it was false or with reckless disregard of whether it was false or not." 9

From the outset, the Court made it clear this requirement would not be easy to meet. It was not met by evidence that the New York Times had in its own files materials showing the falsity of some of the charges against Sullivan; by the Times's Secretary's admission that he suspected one of the charges was false; or by the fact that the newspaper failed to retract at Sullivan's demand, though it had retracted the same charges on the demand of the Governor of Alabama. ${ }^{10}$ Gradually, the Court made it clear that neither malice nor recklessness, in the common law sense of those terms, suffices. Proof of ill will is not enough, ${ }^{11}$ nor is proof that the defendant published without investigating despite an obvious risk of serious harm to reputation. ${ }^{12}$ Instead, what must be shown is a subjective awareness of falsity: that the defendant knew what he was saying was false, or "in fact entertained serious doubts as to the truth of his publication."13 Moreover, knowledge of a merely technical falsehood is not enough; thus, deliberate alteration of quotations is

\footnotetext{
8376 U.S. 254 (1964).

${ }^{9} I d$. at $279-80$.

${ }^{10}$ See id. at 286-88.

11 See Garrison v. Louisiana, 379 U.S. 64, 78-79 (1964).

12 See St. Amant v. Thompson, 390 U.S. 727, 732-33 (1968).

${ }^{13} \mathrm{Id}$. at 731 .
} 
not proof of knowledge of falsity unless the alteration materially changes the meaning of the quotation alleged to be defamatory. ${ }^{14}$

\section{B. Convincing Clarity}

To reinforce this constitutional fortification, the Court greatly expanded judges' control of juries-a development that has had far greater practical effect than the actual malice rule itself. This expansion of judicial control began in New York Times, which intimated that "actual malice" must be proved with "convincing clarity." 15 This means the jury must be instructed that although other issues are controlled by the usual preponderance-of-evidence standard, ${ }^{16}$ actual malice must be shown by "clear and convincing proof." 17 The importance of this rule lies not in its effect on juries, however, but in its effect on judicial review. New York Times also held that judges-from the trial judge to members of the Supreme Court-must engage in independent review of a jury finding of actual malice to satisfy themselves that the evidence is constitutionally sufficient. ${ }^{18}$ In making this sufficiency judgment, judges must determine not merely that the finding is supported by competent evidence, or that a reasonable person could find actual malice, but that it is shown with convincing clarity. The Supreme Court has never explained what that phrase means, but it obviously enhances judges' power to overturn jury verdicts that under usual rules would have to be accepted. The convincing clarity standard also provides the measure by which the genuineness of the actual

14 See Masson v. New Yorker Magazine, Inc., 111 S. Ct. 2419, 2433 (1991).

${ }^{15}$ New York Times, 376 U.S. at 285-86.

${ }^{16}$ See Harte-Hanks Communications, Inc. y. Connaughton, 491 U.S. 657, 661 n.2 (1989).

${ }^{17}$ Id. at 659.

${ }^{18}$ It was not clear in the New York Times decision itself that these were distinct rules. The Court merely asserted that "considerations of effective judicial administration require us to review the evidence in the present record to determine whether it could constitutionally support a judgment for respondent." New York Times, 376 U.S. at 284-85. After engaging in that review, the Court concluded that "the proof presented to show actual malice lacks the convincing clarity which the constitutional standard demands." Id. at 285-86. It did not explain why the Constitution required either a judicial review of evidence or a heightened standard of proof. These soon emerged, however, as important rules in their own right. See Rosenbloom v. Metromedia, Inc., 403 U.S. 29, 55 (1971); Greenbelt Coop. Publishing Ass'n v. Bresler, 398 U.S. 6, 11 (1970). 
malice issue must be judged on defendant's motion for summary judgment under the federal rules. ${ }^{19}$

\section{Independent Review}

The independent review requirement abrogates the usual rule that jury determinations are not to be set aside unless clearly erroneous.

The question whether the evidence in the record in a defamation case is of the convincing clarity required to strip the utterance of First Amendment protection is not merely a question for the trier of fact. Judges, as expositors of the Constitution, must independently decide whether the evidence in the record is sufficient to cross the constitutional threshold that bars the entry of any judgment that is not supported by clear and convincing proof of "actual malice." 20

Lower courts sometimes refer to this as "de novo" review, ${ }^{21}$ but the Supreme Court has never used that term and it is clear that jury findings are not to be disregarded entirely. Indeed, in its own review of actual malice findings, the Court seems to take some pains to avoid contradicting jury findings. ${ }^{22}$ But whatever the Court means by "independent review," there is no doubt that it invites judges to set aside jury determinations.

Although the Court once stated that findings of fact other than actual malice are not to be disturbed unless clearly erroneous, ${ }^{23}$ the Court has decided for itself several other issues that normally would be considered fact issues. One is whether the defamatory statement refers to the plaintiff. The common law notion of colloquium allows an unnamed person to prove that readers nevertheless would reasonably infer that the statement was "of and

${ }^{19}$ See infra text accompanying notes 41-43.

${ }^{20}$ Bose Corp. v. Consumers Union, Inc., 466 U.S. 485, 511 (1984).

${ }^{21}$ See, e.g., Bose Corp. v. Consumers Union, Inc., 692 F.2d 189, 195 (1st Cir. 1982), affd, 466 U.S. 485 (1984).

${ }^{22}$ Libel defendants have tried to convert the independent review rule into a requirement of de novo review, i.e., one that disregards the jury's findings altogether. The Court, however, has refused to take that step. See Harte-Hanks Communications, Inc. v. Connaughton, 491 U.S. 657, 688-89 (1989). In Connaughton, the Court held that the jury's credibility determinations must be accepted unless they are clearly erroneous. See id. Whether the clearly erroneous standard also governs review of other subsidiary fact findings from which the jury infers actual malice has not been decided. See id. at 689-90.

${ }^{23}$ See Bose Corp., 466 U.S. at 514 n.31. 
concerning" the plaintiff. ${ }^{24}$ The jury in New York Times found that readers would infer that the accusations of misconduct made against police officers under Sullivan's command implicitly defamed him. The Court said basing a verdict for the plaintiff on such an inference was tantamount to seditious libel, "transmuting criticism of government, however impersonal it may seem on its face, into personal criticism, and hence potential libel, of the officials of whom the government is composed." 25 Because such an inference was the only basis for the jury's finding that the publication referred to Sullivan, the Court held that "the evidence was constitutionally ... incapable of supporting the jury's finding that the allegedly libelous statements were made 'of and concerning' respondent." ${ }^{26}$

The Court has also reviewed the substantiality of a media defendant's factual error. In New York Times, the Court noted that some of the ad's allegations were false only in degree; "[ $t]$ he ruling that these discrepancies between what was true and what was asserted were sufficient to injure respondent's reputation may itself raise constitutional problems, but we need not consider them here. $" 27$

In Time, Inc. v. Pape ${ }^{28}$ the Court did consider the matter. Time magazine reported that the Civil Rights Commission had concluded that Pape had committed acts of police brutality; in fact, the

${ }^{24}$ See, e.g., Bindrim v. Mitchell, 155 Cal. Rptr. 29 (Cal. Ct. App. 2d) (holding that readers could reasonably identify a purportedly fictional character as the plaintiff), cert. denied, 444 U.S. 984 (1979).

${ }^{25}$ New York Times, 376 U.S. at 292. This was the primary basis of the Times's appeal. The actual malice standard was an alternative argument advanced by the Times. It reportedly was embraced by Justice Brennan after the Court in conference had agreed to reverse on the ground that the Constitution required the common law elements of defamation to be proven with convincing clarity in a suit by a public official against a critic of his official conduct. According to this report, the independent review requirement evolved from extended negotiations among Justices Clark, Harlan, Black, and Brennan over appropriate means of preventing retrial. See MAKE No LAW, supra note 3, at 120-21, 172-81; see also BERNARD SCHWARTZ, SUPER CHIEF 532-34 (1983).

${ }^{26}$ New York Times, 376 U.S. at 288 . This review is probably not applicable to the identification-of-plaintiff issue generally, but only when identification is sought to be established by an inference that smacks of seditious libel. The Court has not reviewed evidence on this issue in any case since New York Times v. Sullivan. Nevertheless, review of the issue even in that limited context suggests that the Court's power to engage in extraordinary review of jury findings arises not from something peculiar to the actual malice issue, but from a more general concern for the impact of particular fact-findings on speech issues in defamation cases.

${ }^{27} I d$. at 289.

${ }^{28} 401$ U.S. 279 (1971). 
Commission had concluded only that the allegations against him appeared substantial enough to warrant inclusion in its report. The Court held that such a minor discrepancy could not support a finding of actual malice. ${ }^{29}$ The inquiry, however, seems to relate more to the issue of falsity than to proof of actual malice. Whether defendant had knowledge of falsity or serious doubts as to the truth is not dependent on the magnitude of the error. Rather, the issue seems to be closer to that mentioned in New York Times: was the difference between the truth and the defamatory allegation substantial enough to justify a judgment that the latter harmed the plaintiff in some way that the former did not. In any event, it involves the Court in a constitutionally based review of matters that normally would be resolved by the common law doctrine of substantial truth. ${ }^{30}$

The Court has also intervened aggressively in cases involving hyperbole or satire, sometimes deciding for itself whether the words used can be construed as defamatory. ${ }^{31}$ Whether other issues may also be subject to independent review is open to question. The rationale-that judges must determine whether the evidence is constitutionally sufficient to surmount the constitutional barrier erected by the actual malice standard-seems equally applicable to any other constitutional prerequisite. Media defendants sometimes claim they are entitled to independent review of all constitutional defamation issues. ${ }^{32}$ Some courts have extrapolated the even broader principle that independent review is required not only in libel cases, but in any case in which a restriction on speech is held constitutional. ${ }^{33}$ The scope of independent review remains unclear, in part because courts sometimes reverse judgments

${ }^{29}$ See id. at 289.

${ }^{30}$ See, e.g., Gomba v. McLaughlin, 504 P.2d 337, 339 (Colo. 1972) (holding that error is not actionable unless it "produces a different effect upon the reader than that which would be produced by the literal truth of the matter").

31 These cases are discussed below; see infra text accompanying notes 79-109.

32 In Newton v. NBC, 930 F.2d 662 (9th Cir. 1990), cert. denied, 112 S. Ct. 192 (1991), the defendants demanded independent review not only of jury findings on constitutional issues, but also of the jury's finding of hatred or ill will to meet the state law standard for punitive damages. See Brief of Appellants at 48 n.44, Newton (Nos. 89-55220, 89-55285). (The author was of counsel to the plaintiff in Newton.) But see McCoy v. Hearst Corp., 727 P.2d 711, 715-16 (Cal. 1986) ("Thus, this court must make an independent assessment of the entire record, but only as it pertains to actual malice. Issues apart from this constitutional question need not be reviewed de novo and are subject to the usual rules of appellate review."), cert. denied, 481 U.S. 1041 (1987).

${ }^{33}$ See Daily Herald Co. v. Munro, 838 F.2d 380, 383 (9th Cir. 1988). 
without making clear whether they are exercising the kind of independent review described in New York Times $v$. Sullivan, or the more conventional power to set aside findings they deem "clearly erroneous" or unsupported by evidence. ${ }^{34}$

Whatever its proper scope, independent review is available only to defendants. ${ }^{35}$ Its purpose is to assure "that the judgment does not constitute a forbidden intrusion on the field of free expression" 36 not to assure that the judgment does not unnecessarily sacrifice reputation.

\section{Summary Judgment}

The Court has transferred power from juries to judges in yet another way by encouraging trial judges to grant defendants' motions for summary judgment. The Court has never endorsed the view of some lower courts that summary judgment should be a preferred remedy in defamation cases to protect the press from the chilling effect of extended litigation. ${ }^{37}$ At one point the Court suggested the contrary: that summary judgment might be the exception rather than the rule in libel cases because the actual malice issue, involving the defendant's state of mind, does not lend itself readily to summary disposition. ${ }^{38}$ Once judges were invited to decide the actual malice issue for themselves after trial, however, it was inevitable that they would be inclined to do so before trial as well. In practice, the defendant's ostensible summary judgment burden of negating the existence of any genuine issue of material fact became a burden on plaintiffs to show affirmatively a basis on which a finding of actual malice might be made. ${ }^{39}$ As a result,

${ }^{34}$ See, e.g., Smith v. Suburban Restaurants, Inc., 373 N.E.2d 215, 218 (Mass. 1978) (finding that summary judgment. was improper on the ground that a jury might reasonably have viewed the letter in question as defamatory).

${ }^{35}$ See, e.g., Brown v. K.N.D. Corp., 529 A.2d 1292, 1294-95 (Conn. 1987) (holding that the appellate court should use the "clearly erroneous" standard of review when, at the trial level, there is a finding for the defendant).

${ }^{36}$ New York Times, 376 U.S. at 285.

${ }^{37}$ See, e.g., Bon Air Hotel v. Time, Inc., 426 F.2d 858, 865 (5th Gir. 1970) (noting that summary judgment assures the press freedom from legal harassment and, thus, self-censorship).

${ }^{38}$ See Hutchinson v. Proxmire, 443 U.S. 111, 120 n.9 (1979).

${ }^{39}$ See, e.g., Liberty Lobby, Inc. v. Dow Jones \& Co., 838 F.2d 1287, 1293 (D.C. Cir.) (stating that the "plaintiff must demonstrate that the defendant himself entertained a 'high degree of awareness of ... probable falsity' [and that] [t]his requirement, too, is applicable when considering a motion for summary judgment" (quoting Garrison v. Louisiana, 379 U.S. 64, 74 (1964))), cert. denied, 488 U.S. 825 
media defendants' motions for summary judgment enjoy unusually high success rates. ${ }^{40}$

When the Court eventually decided an issue of summary judgment procedure, it held that under the Federal Rules of Civil Procedure the clear and convincing proof standard controls at the summary judgment stage as well as at trial. ${ }^{41}$ To survive the defendant's Rule 56 motion for summary judgment in a libel case controlled by New York Times, a plaintiff must produce not merely some evidence to create a genuine issue as to the existence of actual malice, but evidence from which actual malice could be found by clear and convincing proof. ${ }^{42}$ The enhanced standard of proof also controls when a defendant claiming the protections of New York Times moves for a directed verdict. ${ }^{43}$ The Court's earlier suggestion that summary judgment might be inappropriate on the actual malice issue was dismissed as "simply an acknowledgement of our general reluctance 'to grant special procedural protections to defendants in libel and defamation actions." 44 Because the new rule was applicable to any type of case in which a party faced an enhanced evidentiary standard, it did not amount to such a special protection. ${ }^{45}$ The consequence is that judges are encouraged to take the actual malice issue away from the jury before trial, both informally, by the logic of independent judicial review, and formally, by the application of the convincing clarity standard even in the preliminary stages of litigation. As a result, only a small proportion of libel suits governed by New York Times $v$. Sullivan ever reach a jury. ${ }^{46}$

(1988).

40 In one study of 110 summary judgment motions by media defendants in 1980$81,74 \%$ of the motions were granted in cases involving public figure or public official plaintiffs. See Summary Judgment in Libel Litigation: Assessing the Impact of Hutchinson v. Proxmire, LiBEL DEF. RESOURCE CENTER BULL. No. 4 (LDRC, New York, N.Y.), Oct. 15, 1982, at 2 [hereinafter LIBEL DEFENSE BULLETIN].

${ }^{41}$ See Anderson v. Liberty Lobby, Inc., 477 U.S. 242, $254-55$ (1986).

$42 \mathrm{See} i d$. at 244 . For an analysis of the effect of this rule on litigation strategy, see Samuel Issacharoff \& George Loewenstein, Second Thoughts About Summary Judgment, 100 YALE L.J. 73 (1990).

${ }^{43}$ See Anderson, 477 U.S. at 251-52.

${ }^{44} I d$. at $256 \mathrm{n.7}$ (quoting Calder v. Jones, 465 U.S. 783, 790-91 (1984)).

45 See id. at 257 n.1 (Brennan, J., dissenting).

${ }^{46}$ See Marc A. Franklin, Winners and Losers and Why: A Study of Defamation Litigation, 1980 AM. B. FoUND. RES. J. 455, 492 (noting that media defendants won before trial in $68 \%$ of cases involving the New York Times rule). 


\section{E. Public Figures}

These constitutional rules applied only to libel suits by public officials originally, but they now govern most libel cases. The Court extended the requirements of New York Times $v$. Sullivan to candidates for public office ${ }^{47}$ and appointed officials, reaching down "at the very least to those among the hierarchy of government employees who have, or appear to the public to have, substantial responsibility for or control over the conduct of governmental affairs." ${ }^{48}$ The same requirements were also extended to plaintiffs who hold no official position, but "are nevertheless intimately involved in the resolution of important public questions or, by reason of their fame, shape events in areas of concern to society at large." ${ }^{49}$ The lower courts have tended to view both the public official and public figure categories expansively. Police officers, for example, are almost invariably classified as public officials, no matter how low their rank. ${ }^{50}$ The public figure category includes not only those who seek to influence public affairs, ${ }^{51}$ but also those who attract media attention by success in their careers ${ }^{52}$ or avocations $^{53}$ or by their relationships with celebrities. ${ }^{54}$ The plaintiff's fame or influence need not be widespread; notoriety within a particular circle is sufficient to make a person a public figure for purposes of defamation within that circle. ${ }^{55}$

47 See Ocala Star-Banner Co. v. Damron, 401 U.S. 295 (1971); Monitor Patriot Co. v. Roy, 401 U.S. 265 (1971).

${ }^{48}$ Rosenblatt v. Baer, 383 U.S. 75, 85 (1966).

${ }^{49}$ Curtis Publishing Co. v. Butts, 388 U.S. 130, 164 (1967) (Warren, C.J., concurring in the result).

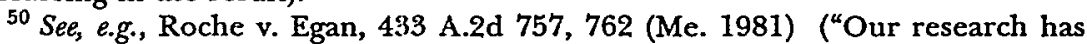
disclosed that every court that has faced the issue has decided that an officer of law enforcement, from ordinary patrolman to Chief of Police, is a 'public official' within the meaning of federal constitutional law.")

51 See, e.g., Associated Press v. Walker, 388 U.S. 130, 154 (1967) (finding a politically prominent man who was active in college campus riot a "public figure").

52 See, e.g., Chuy v. Philadelphia Eagles Football Club, 595 F.2d 1265, 1280 (3d Cir. 1979) (en banc) (professional football player); James v. Gannett Co., 353 N.E.2d 834, 839 (N.Y. 1976) (belly dancer).

${ }^{53}$ See, e.g., Holt v. Cox Enters., 590 F. Supp. 408, 412 (N.D. Ga. 1984) (college football player).

${ }^{54}$ See, e.g., Brewer v. Memphis Publishing Co., 626 F.2d 1238, 1255 (5th Gir. 1980) (former girlfriend of Elvis Presley, wife of retired football star), cert. denied, 452 U.S. 962 (1981).

55 See, e.g., Waldbaum v. Fairchild Publications, Inc., 627 F.2d 1287, 1300 (D.C. Cir.) (innovator in grocery business was public figure for limited purpose of comment on his own business), cert. denied, 449 U.S. 898 (1980); Williams v. Pasma, 656 P.2d 212,216 (Mont. 1982) (former candidate for U.S. Senate who was well-known in state 
The upshot is that the vast majority of those whose activities are likely to attract media attention-and who therefore are at risk of being defamed in the media-are subject to the actual malice rule and the phalanx of other rules that surround it.

The classification of plaintiffs might seem to be primarily factual, depending on the nature of the person's position and responsibilities (if the person is alleged to be a public official) or the scope of the person's fame or involvement in public issues (if the person is alleged to be a public figure). But the lower courts almost universally treat the question as one of law, to be decided by judges not juries. ${ }^{56}$

\section{F. Private Plaintiffs}

Plaintiffs who avoid the public official and public figure classifications find their defamation claims only slightly less restricted by constitutional rules. Private persons who are defamed in discussions about matters of public concern may recover for their actual injury without meeting the requirements described above, provided that they show that the defendant acted with some degree of fault, for example, negligence. ${ }^{57}$ Only if they seek something more than compensation for actual injury, namely presumed damages or punitive damages, must they meet the actual malice test ${ }^{58}$ (and perhaps the other requirements of New York Times $v$. Sullivan). ${ }^{59}$ Actual injury includes "impairment of reputation and standing in the community, personal humiliation, and mental

was public figure), cert. denied, 461 U.S. 945 (1983).

${ }^{56}$ See, e.g., Kassel v. Gannett Co., 875 F.2d 935, 940 (1st Cir. 1989) (holding that under federal law, the public official and public figure questions are for the court); White v. Mobile Press Register, Inc., 514 So. 2d 902, 904 (Ala. 1987) (affirming summary judgment against EPA administrator who the lower court found to be a public figure). The Supreme Court has said only that "as is the case with questions of privilege generally, it is for the trial judge in the first instance to determine whether the proofs show respondent to be a 'public official." Rosenblatt v. Baer, 383 U.S. 75, 88 (1966).

57 See Gertz v. Robert Welch, Inc., 418 U.S. 323, 347 (1974).

58 See id. at 349.

${ }^{59}$ Compare Meadows v. Taft Broadcasting Co., 40 N.Y.S.2d 205 (N.Y. App. Div. 1983) (private plaintiff seeking punitive damages must prove actual malice with convincing clarity) with Pirre v. Printing Devs., Inc., 468 F. Supp. 1028 (S.D.N.Y.) (private plaintiff seeking punitive damages need only prove actual malice by preponderance of evidence), affd mem., 614 F.2d 1290 (2d Cir. 1979). Cases on both sides are discussed in Marcone v. Penthouse International, Ltd., 577 F. Supp. 318, 326-28 (E.D. Pa. 1983), rev'd on other grounds, 754 F.2d 1072 (3d Cir. 1985). 
anguish and suffering. ${ }^{" 60}$ Unlike the tort concept of special damage, actual injury is not limited to out-of-pocket loss: "[A]11 awards must be supported by competent evidence concerning the injury, although there need be no evidence which assigns an actual dollar value to the injury. ${ }^{\prime 61}$ Surprisingly, perhaps, actual injury need not include any harm to reputation; if a state chooses to allow a defamation action for mental anguish alone, unaccompanied by any claim for harm to reputation, the actual injury requirement is not offended. ${ }^{62}$

Yet another set of rules governs some private-plaintiff cases. The scheme described in the preceding paragraph applies to private persons defamed in connection with matters of public concern. Because "speech on matters of purely private concern is of less First Amendment concern," ${ }^{63}$ private plaintiffs defamed in speech of that kind may recover presumed and punitive damages without showing actual malice. ${ }^{64}$ Whether such plaintiffs are also relieved from meeting the fault requirement of Gertz has not been decided. ${ }^{65}$

In practice, few suits proceed under the negligence standard, ${ }^{66}$ because plaintiffs rarely sue for actual injury only. This may be because they are unable to prove actual injury and thus must seek presumed damages, or because they wish to punish the defendant and thus seek punitive damages. Even if they have a modest amount of provable actual injury and no desire to further punish the defendant, the economics of litigation are likely to steer them away from the negligence-actual injury system and into the actual malice scheme. Since the law provides no other method by which a plaintiff of modest means can finance the litigation, the plaintiff's

${ }^{60}$ Gertz, 418 U.S. at 350 .

${ }^{61} \mathrm{Id}$.

62 See Time, Inc., v. Firestone, 424 U.S. 448, 460 (1976).

${ }^{63}$ Dun \& Bradstreet, Inc. v. Greenmoss Builders, Inc., 472 U.S. 749, 759 (1985).

${ }^{64}$ See id. at 761.

${ }^{65}$ See id. at 773-74 (White, J., concurring in the judgment) (" $[I] \mathrm{t}$ must be that the Gerlz requirement of some kind of fault on the part of the defendant is also inapplicable in cases such as this."). There is also some uncertainty about the applicability of the New York Times requirements when the defamation occurs in advertising. See United States Healthcare, Inc. v. Blue Cross, 898 F.2d 914, 924 (3d Cir.) (distinguishing between defamation and commercial disparagement), cert. denied, 111 S. Ct. 58 (1990).

${ }^{66}$ One study of appellate cases found 75 cases in which New York Times $v$. Sullivan supplied the controlling constitutional principles and only 24 in which Gertz was controlling. See Marc A. Franklin, Suing Media for Libel: A Litigation Study, 1981 AM. B. FOUND. RES. J. 795, 824. 
ability to pursue the claim depends on a lawyer's willingness to take the case on contingent fee. ${ }^{67}$ Most lawyers see media defendants as tenacious, well-represented litigants whose insurers generally will honor the defendant's reluctance to settle. The prospective recovery must be large enough to justify the lawyer's investment of time in a protracted and expensive lawsuit that may produce no recovery at all. In most cases, only the prospect of presumed and/ or punitive damages makes the stakes high enough. Even prospective plaintiffs who are able to pay lawyers on a fee-for-time basis must make some similar calculation unless they are liberated by wealth or irrationality from considering the financial consequences of suit. As a result of these pragmatic concerns, suits under the negligence formula of Gertz have turned out to be rare. Thus, the full panoply of constitutional rules developed for public plaintiff cases controls the great majority of libel cases, including those brought by private plaintiffs.

\section{G. Neutral Reportage}

Another constitutional rule, yet to receive either specific approval or condemnation from the Supreme Court, is the "neutral report" privilege. ${ }^{68}$ It creates an absolute privilege for accurate and disinterested reporting of defamatory accusations made by responsible organizations. Where recognized, this privilege protects the media even when they know the charges they are reporting are false, or seriously doubt their truth. As first articulated, the "neutral report" privilege applied only to accusations against public figures, but some jurisdictions have allowed it to be invoked against private plaintiffs as well. ${ }^{69}$

The neutral reportage defense has not been widely embraced, and several important jurisdictions have declined to adopt it. ${ }^{70}$

67 Over $80 \%$ of the plaintiffs in the Iowa Libel Project engaged their lawyers on a contingent fee basis. See LIBEL LAW AND THE PRESS, supra note 3, at 148.

68 The privilege was first recognized in Edwards v. National Audubon Soc., 556 F.2d 113, 120 (2d Cir.), cert. denied, 434 U.S. 1002 (1977).

${ }^{69}$ See April v. Reflector-Herald, Inc., 546 N.E.2d 466, 469 (Ohio Ct. App. 1988) (holding the privilege equally applicable whether plaintiff is public figure or private person).

${ }^{70}$ Among the cases rejecting the privilege are Dickey v. CBS, 583 F.2d 1221 (3d Cir. 1978); McCall v. Courier-Journal, 623 S.W.2d 882 (Ky. 1981), cert. denied, 456 U.S. 975 (1982); Postill v. Booth Newspapers, 325 N.W.2d 511 (Mich. Ct. App. 1982); Hogan v. The Herald Co., 444 N.E.2d 1002 (N.Y. 1982); Janklow v. Viking Press, 378 N.W.2d 875 (S.D. 1985). 
Nevertheless, most jurisdictions probably would apply it in the right case. If the President of the United States baselessly accused the Vice President of plotting to assassinate him, for example, most courts surely would hold that the media could safely report the President's accusation even if they seriously doubted its truth.

\title{
H. Falsity
}

Finally, and perhaps most importantly, the Court has switched the burden of proof on falsity. The universal common law rule that truth was a defense is unconstitutional, and both public and private plaintiffs must now prove the falsity of the defamation. ${ }^{71}$ This is a relatively recent development, the importance of which has yet to be fully appreciated. Much of the Court's dissatisfaction with the common law of libel in New York Times v. Sullivan was, in fact, dissatisfaction with the treatment of truth as a defensive matter:

\begin{abstract}
Allowance of the defense of truth, with the burden of proving it on the defendant, does not mean that only false speech will be deterred. Even courts accepting this defense as an adequate safeguard have recognized the difficulties of adducing legal proofs that the alleged libel was true in all its factual particulars. Under such a rule, would-be critics of official conduct may be deterred from voicing. their criticism, even though it is believed to be true and even though it is in fact true, because of doubt whether it can be proved in court or fear of the expense of having to do so.... The rule thus dampens the vigor and limits the variety of public debate. $^{72}$
\end{abstract}

The unconstitutionality of treating truth as a defense, at least in public official cases, was implied in Garrison $v$. Louisiana, ${ }^{73}$ where the Court said that a public official may recover for libel "only if he establishes that the utterance was false and that it was made with knowledge of its falsity or in reckless disregard of whether it was false or true."74 Even then, many seemed reluctant to believe that the Court meant what it said. The Second Restatement of Torts, for example, expressed no opinion as to whether the burden of proof had been changed by constitutional law. ${ }^{75}$ Finally, in 1986, the

${ }^{71}$ See Philadelphia Newspapers, Inc. v. Hepps, 475 U.S. 767, 775-76 (1986).

${ }^{72}$ Nezv York Times, 376 U.S. at 279 (footnote and citations omitted).

73 379 U.S. 64 (1964).

${ }^{74} I d$. at 74 .

75 See RESTATEMENT (SECOND) OF TORTS $\$ 613$ caveat (1977) ("The Institute expresses no opinion on the extent to which the common law rule placing on the 
Court put the matter to rest, squarely holding that the Constitution requires that plaintiffs bear the burden of proving falsity, in both private-plaintiff and public-plaintiff cases. ${ }^{76}$

In public-plaintiff cases, courts generally have held that plaintiffs must prove falsity by clear and convincing proof. ${ }^{77}$ In Philadelphia Newspapers Inc. v. Hepps the Court found "no occasion to consider the quantity of proof of falsity that a private-figure plaintiff must present." 78

\section{Nonfactual Expressions}

For a time, the lower courts were developing a doctrine so malleable and expansive that it seemed destined to become the most important constitutional restriction on libel law. The doctrine was that expressions of opinion were absolutely protected, and it evolved from the following passage in Gertz: "Under the First Amendment there is no such thing as a false idea. However pernicious an opinion may seem, we depend for its correction not on the conscience of judges and juries but on the competition of other ideas."79

Many courts saw in this passage an implication that opinion is constitutionally protected. ${ }^{80}$ Opinion is protected at common law by the privilege of fair comment, but that privilege attaches only if the statement does not imply the existence of undisclosed defamatory facts, ${ }^{81}$ and defamatory statements of opinion often contain such implications. Moreover, the common law privilege is destroyed by proof that the speaker did not honestly hold the opinion stated

defendant the burden of proof to show the truth of the defamatory communication has been changed .....”).

${ }^{76}$ See Philadelphia Newspapers, Inc. v. Hepps, 475 U.S. 767, 775-76 (1986). The Court did not decide whether the burden must be shifted to plaintiffs in nonmedia cases, cases not involving matters of public concern, or cases seeking a declaration of falsity rather than damages. See id. at 779 n.4.

${ }_{77}$ See, e.g., Buckley v. Littell, 539 F.2d 882, 889 (2d Cir. 1976) (stating that a public figure must demonstrate "with convincing clarity" the falsity of defendant's statements), cert. denied, 429 U.S. 1062 (1977); Firestone v. Time, Inc., 460 F.2d 712, 723 (5th Cir.) (Bell, J., concurring) (extending the clear and convincing proof standard to plaintiff's burden of "proving that the statement was false in the first instance"), cert. denied, 409 U.S. 875 (1972).

${ }^{78}$ Hepps, 475 U.S. at 779 n.4.

${ }^{79}$ Gertz v. Robert Welch, Inc., 418 U.S. 323, 339-40 (1974) (footnote omitted).

${ }^{80}$ Numerous cases holding that opinion is constitutionally protected are cited in John B. McCrory et al., Constitutional Privilege in Libel Law, in I CommuNICATIONS LAW 1989, at 403, 420 (Practicing Law Institute ed., 1989).

81 See, e.g., RESTATEMENT (SECOND) OF TORTS $\$ 566$ (1977). 
or spoke for the purpose of harming the plaintiff. ${ }^{82}$ The courts imposed no such limitations on the constitutional protection of opinion. They read Gertz as creating an absolute protection for opinion, so that the defendant's motive and the honesty with which the belief was held were irrelevant. ${ }^{83}$

The most widely used method for distinguishing fact from opinion called for the analysis of four factors to determine whether "the totality of circumstances in which the statements are made" indicated that the average reader would understand them as opinion rather than fact. ${ }^{84}$ The factors were (1) the common meaning of the language used, (2) the verifiability of the statement, (3) the journalistic context in which the statement was made (e.g., editorial column vs. news article), and (4) the setting in which the statement occurred (e.g., political controversy vs. private business dispute). ${ }^{85}$ The result was to give absolute constitutional protection to many highly defamatory statements. Examples include the following: a broadcast characterizing plaintiff as a member of "an 'international network of medical quackery' whose patients were victims of 'cancer con artists"; ${ }^{86}$ a published assertion that plaintiff "is the $\mathrm{Al}$ Capone of the City" ${ }^{87}$ and a review of a television documentary on sex education in which the reviewer stated "My impression is that the executive producer [plaintiff] . . . told his writer/producer ... 'We've got a hot potato here-let's pour on titillating innuendo and as much bare flesh as we can get away with. Viewers will eat it up!'"88

Though some courts construed the doctrine more narrowly, virtually none refused to read Gertz as creating constitutional protection for opinion, and the Supreme Court initially passed up numerous opportunities to review cases applying the constitutional

${ }^{82}$ See id. $\$ 556 \mathrm{cmt}$. a.

${ }^{83}$ See, e.g., Carr v. Brasher, 776 S.W.2d 567, 570 (Tex. 1989) (interpreting Gertz as elevating "to a constitutional principle the distinction between [statements of] fact and opinion," with only the former being actionable).

${ }^{84}$ See Ollman v. Evans, 750 F.2d 970,979 (D.C. Cir. 1984) (en banc), cert. denied, 471 U.S. 1127 (1985).

${ }^{85} \mathrm{See}$ id. Other courts considered additional factors. See, e.g., Information Control Corp. v. Genesis One Computer Corp., 611 F.2d 781, 784 (9th Cir. 1980) (use of cautionary terms and the nature of the audience); Marchiondo v. Brown, 649 P.2d 462, 469 (N.M. 1982) (the likely understanding of reasonably prudent readers).

${ }^{86}$ Kirk v. CBS, 14 Media L. Rep. (BNA) 1263, 1264 (N.D. Ill. 1987).

${ }^{87}$ Rowland v. Fayed, 14 Media L. Rep. (BNA) 1257, 1257 (Sup. Ct. D.C. 1987).

${ }^{88}$ Baker v. Los Angeles Herald Examiner, 721 P.2d 87, 89 (Cal. 1986), cert. denied, 479 U.S. 1032 (1987). 
immunity for opinion. ${ }^{89}$ As a result, the doctrine was the fastestgrowing body of defamation law in the 1980s. Unlike all the other rules that flow from New York Times v. Sullivan, the opinion rule worked at the beginning of litigation. Whether the defamatory statement was opinion often could be determined from the publication itself, or with a minimum of discovery. It therefore could be invoked by a motion to dismiss for failure to state a cause of action or by an early summary judgment motion. Of all the constitutional defamation rules, therefore, the opinion rule best served as an early screening device by which judges could dispose of cases they considered unmeritorious. Perhaps for that reason, it was used to resolve many cases that at common law would not have been thought to involve opinion.

The opinion doctrine died, however, in Milkovich $v$. Lorain Journal Co. ${ }^{90}$ The Supreme Court explicitly refused to adopt the theory that a "separate constitutional privilege for 'opinion' is required to ensure the freedom of expression guaranteed by the First Amendment." 91 The much-quoted sentences from Gertz were not intended "to create a wholesale defamation exemption for anything that might be labeled 'opinion." 92 The Court explained that statements of opinion often convey implications that can cause as much damage to reputation as explicit statements of fact. ${ }^{93}$ It concluded that the other constitutional protections adequately protect the free and uninhibited discussion of public issues, and that any benefits resulting from the proposed privilege for opinion did not outweigh society's "pervasive and strong interest in preventing and redressing attacks upon reputation." 94

Nonetheless, the Court recognized that there are "constitutional limits on the type of speech which may be the subject of state defamation actions." 95 The Court cited cases in which it had examined the language used and determined that it was constitutionally incapable of a defamatory meaning. In Greenbelt Cooperative

${ }^{89}$ See Ault v. Hustler Magazine, 860 F.2d 877 (9th Cir. 1988), cert. denied, 489 U.S. 1080 (1989); Ollman v. Evans, 750 F.2d 970 (D.C. Gir. 1984) (en banc), cert. denied, 471 U.S. 1127 (1985); Baker, 721 P.2d 87; Miskovsky v. Tulsa Tribune, 678 P.2d 242 (Okla. 1983), cert. denied, 465 U.S. 1006 (1984).

90110 S. Ct. 2695 (1990).

91 Id. at 2707.

92 Id. at 2705 .

93 See id. at 2705-06.

${ }^{94} I d$. at 2707 (quoting Rosenblatt v. Baer, 383 U.S. 75, 86 (1966)).

${ }^{95} I d$. at 2704. 
Publishing Association v. Bresler, ${ }^{96}$ the Court reversed the libel judgment won by a developer whose position in negotiations with the city had been characterized as "blackmail." The state courts, analyzing the problem in accordance with established common law tort rules, had held that the word was capable of conveying a defamatory meaning; whether it was so understood therefore was a question for the jury. ${ }^{97}$ But the Supreme Court decided that issue itself, holding that a reasonable reader would not have thought the plaintiff was being charged with the crime of blackmail, but would have understood that the word was "no more than rhetorical hyperbole, a vigorous epithet used by those who considered Bresler's negotiating position extremely unreasonable." ${ }^{\text {98 }}$ The decision established two principles: (1) interpretation of language can be a constitutional issue; ${ }^{99}$ and (2) the reviewing court ultimately does the interpreting, without much regard for traditional judge-jury roles.

The Gourt employed the Bresler analysis by analogy in Old Dominion Branch No. 496, National Association of Letter Carriers v. Austin. ${ }^{100}$ The publication in question quoted Jack London's famous definition of a "scab" as a "traitor to his God, his country, his family and his class," 101 and implied that plaintiffs fit the definition. ${ }^{102}$ The Court held that this implication could not reasonably be understood as defamatory. ${ }^{103}$

The Court employed the first principle of Bresler in Hustler Magazine, Inc. v. Falwell, ${ }^{104}$ and held that an action for intentional infliction of emotional distress was constitutionally precluded where

96398 U.S. 6 (1970).

${ }^{97}$ See Greenbelt Coop. Publishing Ass'n v. Bresler, 252 A.2d 755, 770 (Md. Ct. App. 1969), rev'd, 398 U.S. 6 (1970).

${ }_{98}$ Bresler, 398 U.S. at 14.

${ }^{99}$ If the original decision left any doubt, the Court recently confirmed that whether a statement is reasonably capable of a defamatory meaning is a constitutional issue. See Milkovich, $110 \mathrm{~S}$. Ct. at 2704-05. Although Justice Brennan dissented in Milkovich, he agreed with the majority on this point. Id. at 2708-09 (Brennan, J., dissenting).

100418 U.S. 264 (1974).

101 Id. at 268.

102 See id. at 267-68.

${ }^{103}$ See id. at 285-86. The underlying cause of action was based on federal labor law rather than state tort law, so the Court's decision might be seen as an interpretation of federal labor law rather than constitutional law, but the Court relied on Bresler as precedent and indicated that it was engaging in the same kind of review that is required in First Amendment cases. See id. at 280-82.

104485 U.S. 46 (1988). 
the publication in question was satirical and could not be understood as describing actual facts about the plaintiff. Because the jury had so found in the plaintiff's companion suit for libel, ${ }^{105}$ it was not necessary to invoke the second Bresler principle of independent review.

In Milkovich, the Court interpreted these three cases as providing constitutional protection for "statements that cannot 'reasonably [be] interpreted as stating actual facts' about an individual, ${ }^{" 106}$ and asserted that "[t]his provides assurance that public debate will not suffer for lack of 'imaginative expression' or the 'rhetorical hyperbole' which has traditionally added much to the discourse of our Nation." 107 The Gourt held that these protections, together with the Hepps requirement that "a statement on matters of public concern must be provable as false before there can be liability," provide sufficient protection for opinion. ${ }^{108}$

The remaining question, of course, is "How broad is the exception for statements that do not state actual facts?" The argument for protecting opinion was, in part, that it did not state "actual facts." Dissenting in Milkovich, Justice Brennan labelled as "conjecture" the statements that the lower courts had called opinion, and argued that conjecture is as important to robust discourse as rhetorical hyperbole. ${ }^{109}$ The majority's rejection of that argument makes clear that the exception is not broad enough to swallow up all that previously was protected as opinion. But hyperbole and satire are not the only modes of expression that communicate without stating actual facts, and it seems certain that there will now be pressure to extend the Bresler rationale to many other types of speech.

\section{J. What Remains is Not a General Remedy for Defamation}

Very few victims of defamation have any hope of remedy under this system. Most have no chance unless, in addition to proving publication of a defamatory statement (1) they can produce before trial clear and convincing proof that the defendant seriously doubted the truth of the defamation; (2) the trial judge, jury, and all

105 See id. at 57.

${ }^{106}$ Milkovich, 110 S. Ct. at 2706 (citation omitted) (quoting Falwell, 485 U.S. at $50)$.

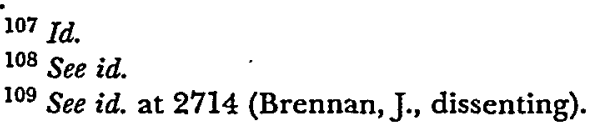


reviewing courts independently agree that such proof is clear and convincing; (3) the accusation is not hyperbolic, rhetorical, satirical, or otherwise incapable of sufficiently precise factual content; (4) the plaintiff is able to prove its falsity, perhaps by the clear-andconvincing standard; and (5) the defendant is not neutrally repeating the defamatory accusation of a responsible organization about a matter of public concern.

The plaintiff who survives this gauntlet may still fall victim to common law rules about special damages, state law privileges, retraction statutes, unusually short statutes of limitations, and other peculiar state limitations. What libel law provides today is not a general remedy with exceptions, but a general scheme of nonliability that permits a remedy only in exceptional cases.

\section{THE RESIDUAL REMEDY}

The problem New York Times v. Sullivan sought to solve was that the common law of libel produced too much self-censorship, deterring critics of official conduct from voicing criticism they believed to be true, "thus dampen[ing] the vigor and limit[ing] the variety of public debate." 110 The complex rules the Court created to solve the problem have not proved to be a happy solution, for reasons that have to do with the way the rules operate in litigation.

\section{A. Protracted Litigation}

The actual malice requirement introduces into every publicplaintiff case $\mathrm{e}^{111}$ a difficult issue that does not lend itself to preliminary disposition. Indeed, the issue does not readily lend itself to disposition at all. Cases that turn on actual malice sometimes continue for ten or fifteen years. ${ }^{112}$

${ }^{110}$ New York Times, 376 U.S. at 279.

111 And because of the limitations on damages that apply if it is not proved, into almost every other case. See supra notes 57-67 and accompanying text.

112 See, e.g., Milkovich v. Lorain Journal Co., 110 S. Ct. 2695 (1990) (15 years); Herbert v. Lando, 781 F.2d 298 (2d Cir.), cert. denied, 476 U.S. 1182 (1986) (12 years); Gertz v. Robert Welch, Inc., 680 F.2d 527 (7th Cir. 1982), cert. denied, 459 U.S. 1226 (1983) (14 years); Sprague v. Philadelphia Newspapers, Inc., Pa. Ct. C.P., Philadelphia County, No. 3644, May 3, 1990, reported in News Notes, 17 Media L. Rep. (BNA) No. 23, May 15, 1990 (17 years). The Milkovich and Sprague decisions cited did not resolve the cases; Milkovich was remanded and Sprague was merely the trial court verdict. 
The actual malice rule makes constitutional protection dependent on the defendant's state of mind. The decisive question is whether "the defendant in fact entertained serious doubts as to the truth of his publication." ${ }^{113}$ This is a complex factual issue that normally cannot be resolved without discovery, sometimes in prodigious quantities. In the most notorious example, a deposition of a television producer "continued intermittently for over a year and filled 26 volumes containing nearly 3,000 pages and 240 exhibits."114 After thirteen years of discovery and discoveryrelated litigation (including two district court decisions, two appeals to the court of appeals, and one Supreme Court decision), the case was dismissed on the ground that there was not sufficient evidence of actual malice to require trial. ${ }^{115}$

Although the actual malice rule is frequently invoked on motion for summary judgment, ${ }^{116}$ it is not a test that lends itself to summary disposition. Want of actual malice will rarely be apparent from the pleadings alone; thus, it does not provide a ground for a motion to dismiss. If the admonition that a summary judgment movant bears the burden of establishing the absence of any genuine issue of material fact is taken seriously, a defendant seeking disposition on this ground has a classic problem of proving a negative: that he did not entertain serious doubts about the truth of the publication. The Supreme Court has said the defendant cannot "automatically insure a favorable verdict by testifying that he published with a belief that the statements were true."117 A fortiori, similar testimony in a self-serving affidavit cannot suffice on motion for summary judgment. ${ }^{118}$

Actual malice, like other state-of-mind determinations, is normally inferred from circumstantial evidence. By way of example, the Supreme Court has said malice might be inferred

113 St. Amant v. Thompson, 390 U.S. 727, 731 (1968).

114 Herbert v. Lando, 441 U.S. 153, 176 n.25 (1979).

115 See Herbert v. Lando, 781 F.2d 298 (2d Cir.), cert. denied, 476 U.S. 1182 (1986).

116 Media defendants' success rate is even higher in summary judgment motiona based on the actual malice issue ( $81 \%$ ) than in summary judgment motions generally (75\%). See LIBEL DEFENSE BULLETIN, supra note 40, at 2.

${ }^{117}$ St. Amant, 390 U.S. at 732.

${ }^{118}$ See Anderson v. Liberty Lobby, Inc., 477 U.S. 242, 255 (1986) ("Our holding ... by no means authorizes trial on affidavits."). For a case interpreting a state summary judgment rule to allow a defendant to prevail solely on the basis of an affidavit that he believed his statement to be true, see Casso v. Brand, 776 S.W.2d 551 (Tex. 1989). 
where a story is fabricated by the defendant, is the product of his imagination, or is based wholly on an unverified anonymous telephone call[, or] ... when the publisher's allegations are so inherently improbable that only a reckless man would have put them in circulation[, or] ... where there are obvious reasons to doubt the veracity of the informant or the accuracy of his reports. 119

One difficulty in attempting to decide such an issue on summary judgment is that appraising the relevant circumstances requires development and review of a large amount of factual evidence. A second and more fundamental difficulty is that deciding what inferences to draw from circumstances is peculiarly a jury function.

To make the actual malice test effective in preventing the chill that would result from fully litigating claims that eventually turn out to be constitutionally barred, the courts have had to bend the rules of summary judgment procedure. Occasionally this is done explicitly. Some of the U.S. courts of appeal, for example, have stated that judges should give such motions special consideration because of the First Amendment interest in preventing the chilling effect on speech that might result from protracted litigation. ${ }^{120}$ More often, the courts achieve the same result sub silentio simply by rigorously scrutinizing the evidence of actual malice offered by the plaintiff in response to the motion. ${ }^{121}$ Summary judgment motions based on want of actual malice tend to be preferred even by courts that do not acknowledge such a preference explicitly. ${ }^{122}$ The empirical evidence tends to corroborate this: one study suggests that about eighty percent of all media libel cases are disposed of by summary judgment. ${ }^{123}$

The Supreme Court has never endorsed the notion that summary judgment is a favored remedy in public-figure libel cases, but it has made it easier for such motions to succeed. Without according any special protection to libel defendants as such, the

119 St. Amant, 390 U.S. at 732.

${ }^{120}$ See Guam Fed'n of Teachers, Local 1581 v. Ysrael, 492 F.2d 438, 441 (9th Cir.), cert. denied, 419 U.S. 872 (1974); Washington Post Co. v. Keogh, 365 F.2d 965, 968 (D.C. Cir. 1966), cert. denied, 385 U.S. 1011 (1967).

${ }^{121}$ See Steaks Unlimited, Inc. v. Deaner, 623 F.2d 264 (3d Cir. 1980); Yiamouyiannis v. Consumers Union of the United States, Inc., 619 F.2d 932 (2d Cir.), cert. denied, 449 U.S. 839 (1980); Tucci v. Gannett Publishing Co., 464 A.2d 161 (Me. 1983).

122 See Robert D. SACK, LIBEL, SLANDER, AND RELATEd PRoblems 542-44 (1980).

${ }^{123}$ See LiBEL DEFENSE Bulletin, supra note 40, at 2. 
Court held, in Anderson v. Liberty Lobby, Inc., ${ }^{124}$ that elevated standards of proof, of which the clear and convincing standard is a prominent example, must be applied under the federal summary judgment rule. The result is that a judge hearing a summary judgment motion in a public-figure libel case must make this mindbending determination: has the defendant established that there is no genuine issue of material fact as to whether plaintiff could prove actual malice by clear and convincing proof? In practice, this means a defendant who supports his or her summary judgment motion with affidavits or other evidence indicating lack of actual malice will win unless the plaintiff can prove actual malice with convincing clarity at that preliminary stage. This creates a formidable early barrier to public-plaintiff libel claims, but only by shifting the difficult matter of proving actual malice from the trial to the discovery stage of litigation. If the plaintiff must prove actual malice with convincing clarity to survive a motion for summary judgment, he or she must be given full opportunity to discover any evidence from which such proof might be inferred. The Anderson Court acknowledged as much: "[T]he plaintiff must present affirmative evidence in order to defeat a properly supported motion for summary judgment. This is true even where the evidence is likely to be within the possession of the defendant, as long as the plaintiff has had a full opportunity to conduct discovery. "125 The actual malice test is thereby made more effective as a device for summary disposition, but only by requiring that a key factual issue in the case be resolved through discovery.

\section{B. Uncontrolled Damages}

At least part of the chilling effect of libel suits results from the possibility of huge damage awards, and the present constitutional law of libel does little to reduce this chill. Public-figure libel litigation usually involves high stakes. In most torts, where the plaintiff must prove the amount of his or her damage, the facts of the case impose some finite ceiling on potential damages. But in public-figure defamation, where damages are presumed, there is no such ceiling. As Justice Powell observed, "[j]uries may award substantial sums as compensation for supposed damage to reputa-

124477 U.S. 242 (1986).

125 Id. at 257. 
tion without any proof that such harm actually occurred."126 The amount is limited only by "the sound discretion of the jury." 127

Punitive damages, though available for all torts in most jurisdictions, are especially likely to be claimed and awarded in these defamation cases. This is not surprising, because a plaintiff who is able to prove knowing or reckless falsity to establish liability is already closer to qualifying for punitive damages than one who need only prove negligence to establish liability. Most states require a showing of ill will or some other species of common law malice in addition to the constitutionally required showing of "actual malice" as a prerequisite for punitive damages, ${ }^{128}$ but the former often can be inferred from the same evidence as the latter. ${ }^{129}$

Because of the availability of presumed and punitive damages, public-figure defamation claimants often seek millions of dollars in damages. Defendants must take such claims seriously, because juries sometimes do. Juries have returned verdicts exceeding fifteen million dollars in a number of public-figure defamation cases against the media. ${ }^{130}$ The average verdict in such cases in 1989 and 1990 exceeded four million dollars; ${ }^{131}$ one study found

${ }^{126}$ Gertz v. Robert Welch, Inc., 418 U.S. 323, 349 (1974). 1916).

1274 J.G. SUTHERLAND, A TREATISE ON THE LAW OF DAMAGES, $§ 1206$ (4th ed.

${ }^{128}$ See, e.g., Burnett v. National Enquirer, 144 Cal. Rptr. 206, 222 (Cal. Ct. App. 1983) (holding that "malice in fact" or ill will is required in addition to "malice in law" to permit punitive damages in libel actions), appeal dismissed, 465 U.S. 1014 (1984); Gannett Co. v. Re, 496 A.2d 553, 559 (Del. 1985) (holding that states are not bound by the actual malice standard and may impose additional burdens on plaintiffs seeking punitive damages in libel actions); Mahoney v. Adirondack Publishing Co., 509 N.Y.S.2d 193, 200 (1986) (holding that the imposition of punitive damages in libel actions requires proof of common law malice in addition to proof of malice in its constitutional sense), rev'd on other grounds, 517 N.E.2d 1365 (N.Y. 1987).

${ }^{129}$ See, e.g., Sharon v. Time, Inc., 599 F. Supp. 538, 587 (S.D.N.Y. 1984) (holding that common law malice or ill will can be inferred from evidence proving "constitutional" malice for the purpose of allowing punitive damages in a libel action).

${ }^{130}$ See Newton v. NBC, 930 F.2d 662 (9th Cir. 1990) (\$19.3 million verdict), cert. denied, 112 S. Ct. 192 (1991); Lerman v. Flynt Distrib. Co., 745 F.2d 123 (2d Cir. 1984) (\$40 million verdict), cert. denied, 471 U.S. 1054 (1985); Pring v. Penthouse Int'l, Ltd. 695 F.2d 438 (10th Cir. 1982) ( $\$ 26.5$ million verdict), cert. denied, 462 U.S. 1132 (1983); Guccione v. Hustler Magazine, Inc., 7 Media L. Rep. (BNA) 2077 (Ohio Ct. App. 1981) ( $\$ 40.3$ million verdict); Sprague v. Philadelphia Newspapers, Inc., No. 3644 (Pa. Ct. C.P., Philadelphia County, May 3, 1990), reported in News Notes, 17 Media L. Rep. (BNA) No. 23, May 15, 1990) (\$34 million); Feazell v. Belo Broadcasting Corp., (Tex Dist. Ct., McLennan County, June 7, 1991), reported in WALl ST. J., June 28,1991 , at B4 (\$58 million); Srivastava v. Harte-Hanks Television Inc., No. 85CI-15150 (Texas Dist. Ct., Apr. 15, 1990), reported in News Notes, 17 Media L. Rep. (BNA) No. 25, May 29, 1990 (\$29 million).

131 See Alex S. Jones, News Media's Libel Costs Rising, Study Says, N.Y. TIMEs, Sept. 
average libel verdicts to be three times as high as average verdicts in medical malpractice and product liability litigation. ${ }^{132}$ Such enormous verdicts rarely survive appeal: the largest affirmed to date in a media case is $\$ 3,050,000 .{ }^{133}$ Nonetheless, the size of potential recoveries escalates the chilling effect in several ways.

First, large verdicts exact a financial penalty even when they are later reversed. Until they are overturned, they are contingent liabilities on the defendant's balance sheet, threatening the defendant's ability to secure financing or acquire or be acquired by other entities. The appeal itself often exacts a substantial price. In a jurisdiction that requires a supersedeas bond commensurate with the size of the judgment, a large verdict pressures the defendant to settle even when an appeal would be likely to succeed. ${ }^{134}$

Second, even a remote possibility of suffering a catastrophic loss is sobering. Even if the defendant's counsel believes such a loss is highly unlikely, he or she cannot assure the client that it will not happen. The apparent high stakes, therefore, probably have a stronger effect in terrorem than the actual loss experience of the media would dictate.

Third, the high stakes make it all but inevitable that litigating the claim will be expensive and time-consuming. If the maximum loss were, say, $\$ 200,000$, there would be an effective limit on the amount of time and money that could be rationally devoted to either the prosecution or defense of the claim. When the potential loss is unpredictable, however, it is more difficult for either side to know how much effort is justified. The result is that both sides are likely to spend more in litigation costs than the actual chances of recovery would indicate. This is probably one reason why legal fees account for about eighty percent of the total cost of libel suits

26,1991 , at A28. The average verdict for the decade $1981-90$ was $\$ 1.8$ million. See News Notes, LDRC Finds Increase in Media Damage Awards, 19 Media L. Rep. (BNA) No. 9, Oct. 8, 1991.

132 See Juries and Damages: Comparing the Media's Libel Experience to Other Civil Litigants, LIBEL DEF. RESOURCE CENTER BULL. NO. 9 (LDRC, New York, N.Y.), Jan. 31,1984 , at 28.

${ }^{139}$ See Brown \& Williamson Tobacco Corp. v. Jacobson, 827 F.2d 1119 (7th Cir. 1987), cert. denied, 485 U.S. 933 (1988).

${ }^{134}$ The cost of a supersedeas bond, which prevents plaintiff from collecting the judgment pending appeal, is usually a percentage of the amount of the verdict. A television company that would have been required to post a $\$ 58$ million bond to appeal a libel judgment in that amount settled for an undisclosed sum rather than pursue the appeal. See A.H. Belo Broadcast Unit Settles Libel Suit in Texas, WALL ST. J., June 28, 1991 , at B4. 
against the press. ${ }^{135}$ For many potential defendants, the most relevant source of the chilling effect is not the danger of losing a judgment, but the prospect of having to pay the costs of defending. ${ }^{136}$ To the extent that New York Times $v$. Sullivan discourages plaintiffs from suing, it reduces this source of self-censorship. But against this benefit must be weighed the possibility that the actual malice rule tends to increase potential verdicts and/or defense costs.

\section{Intrusion into Editorial Processes}

In other contexts, the Supreme Court is sensitive to the dangers of judicial intrusion into editorial matters. For example, it invalidated Florida's "right of reply" statute, partly on the ground that the remedy would involve the courts too deeply in the editorial process. ${ }^{137}$ Yet it is hard to conceive of any legal rule that would involve the courts more deeply in that process than the actual malice rule does.

Under that rule, constitutional protection turns not on what is published, or on the objective truth or falsity of what is published, but on defendants' knowledge or doubts with respect to falsity. Courts are required to determine what defendants thought, and because only defendants know the answer to that, it would hardly do to accept their self-serving testimony as conclusive. So defendants' thoughts are usually inferred from what they did or said. ${ }^{138}$

Inferring state of mind from circumstantial evidence invites the following kinds of inquiries:

What a reporter said to an editor, or vice versa. ${ }^{139}$ Did either express doubts as to the truth of the defamatory matter? Mention contradictory evidence? Question credibility of sources? Express skepticism about the accusations? Suggest further investigation? A defendant who admits having engaged in these journalistically

135 See SMOLLA, SUING, supra note 3 , at 75 (1986).

${ }^{136} \mathrm{See}$ id. at 74.

${ }^{137}$ See Miami Herald Publishing Co. v. Tornillo, 418 U.S. 241, 261 (1974) (White, J., concurring).

${ }^{138}$ See, e.g., Herbert v. Lando, 441 U.S. 153, 160 (1979) (“[P]roof of the [defendant's] necessary state of mind could be in the form of objective circumstances from which the ultimate fact could be inferred . ..."); Tavoulareas v. Piro, 817 F.2d 762, 789 (D.C. Cir.) (en banc) ("[A] plaintiff may prove the defendant's subjective state of mind through the cumulation of circumstantial evidence . . . "), cert. denied, 484 U.S. 870 (1987).

${ }^{139}$ See Herbert, 441 U.S. at 174. 
desirable discussions risks weakening the defense by giving the plaintiff a basis for inferring the existence of serious doubts. Moreover, the plaintiff need not accept the defendant's conclusory answers on questions of this sort; under general principles of discovery, the plaintiff is entitled to probe all that was said, and make his or her own decision as to whether the conversation suggested skepticism, reservations, or incredulity.

Information that defendant possessed or considered but did not include in the article. ${ }^{140}$ Evidence that the defendant had information conclusively refuting the defamatory allegation would be proof of knowing falsehood. Evidence that the defendant had information contradicting the allegation may support an inference of serious doubts. ${ }^{141}$ The plaintiff therefore is entitled to discover pertinent information in the defendant's possession to determine what inferences might be drawn from it. Reporters' notes, tape recordings, investigative files, correspondence, clippings, and outtakes thus become targets of discovery. ${ }^{142}$

Defendant's attitudes toward plaintiff, toward the subject discussed in the defamatory article, and toward journalism. A showing that the defendant harbored ill will toward the plaintiff, the sort of common law malice that might support an award of punitive damages, is not evidence of actual malice. ${ }^{143}$ Such evidence is admissible, however, to show why the defendant might have published despite serious doubts. ${ }^{144}$ A history of conflict between the defendant and

${ }^{140}$ See, e.g., Robertson v. McCloskey, 666 F. Supp. 241, 250-51 (D.D.C. 1987) (holding that evidence in defendant's possession contradicting the allegedly defamatory statements is relevant in determining defendant's state of mind).

${ }^{141}$ See Hunt v. Liberty Lobby, 720 F.2d 631, 645 (11th Cir. 1983); Montandon v. Triangle Publications, Inc., 120 Cal. Rptr. 186, cert. denied, 423 U.S. 893 (1975).

142 Of course, discovery of these materials may be thwarted by claims of privilege or other limitations on discovery. See, e.g., Contemporary Mission, Inc. v. New York Times, 665 F. Supp. 248, 268-69 (S.D.N.Y. 1987) (denying additional discovery where evidence would be cumulative), aff d, 842 F.2d 612 (2d Cir.), cert. denied, 488 U.S. 856 (1988); Lal v. CBS, Inc., 551 F. Supp. 356, 363-62 (E.D. Pa. 1982) (noting that a television reporter's notes, scripts, and outtakes were privileged under state statute), aff $d, 726$ F.2d 97 (3d Cir. 1984).

${ }^{143}$ See Greenbelt Coop. Publishing Ass'n v. Bresler, 398 U.S. 6, 10-11 (1970); Garrison v. Louisiana, 379 U.S. 64, 71-73 (1964).

${ }^{144}$ See Sharon v. Time, Inc., 599 F. Supp. 538, 584 (S.D.N.Y. 1984) (stating that although evidence of bias could not establish actual malice, such evidence could provide a motive for defamation or explain unsupported conclusions in the published material); Cochran v. Indianapolis Newspapers, Inc., 372 N.E.2d 1211, 1220 (Ind. Ct. App. 1978) (stating that ill will is "relevant and admissible as evidence in the determination of whether defendant possessed a state of mind highly conducive to reckless disregard of falsity," even though ill will is not itself an element of actual 
plaintiff may be admissible for the same reason. ${ }^{145}$ Evidence that the defendant espoused a particular journalistic philosophy or objective (e.g., "sophisticated muckraking") may be admissible to permit an adverse inference to be drawn from the defendant's failure to adequately investigate. ${ }^{146}$

The competitive and joumalistic pressures under which the defamatory material was prepared and published. Courts sometimes suggest that reckless disregard might be inferred from failure to investigate when the matter is not "hot news." 147 This proposition is controversial, ${ }^{148}$ but the converse-that the urgency of publication or the immediacy of deadlines is a circumstance preventing the drawing of adverse inferences from failure to investigate-is generally accepted. ${ }^{149}$ How the publisher viewed the urgency of the story, and why, is therefore a legitimate matter for inquiry.

The sufficiency of the defendant's jourmalistic efforts. Although it is clear that failure to investigate is not in itself evidence of reckless disregard, ${ }^{150}$ it is equally clear that other circumstantial evidence may make such a failure relevant. ${ }^{151}$ Inherently improbable

malice).

145 See Indianapolis Newspapers, Inc., v. Fields, 259 N.E.2d 651, 663-64 (Ind.), cert. denied, 400 U.S. 930 (1970).

${ }^{146}$ See Curtis Publishing Co. v. Butts, 388 U.S. 130, 158 (1967).

147 See id. at 157; Carson v. Allied News Co., 529 F.2d 206, 211 (7th Cir. 1976); Vandenburg v. Newsweek, Inc., 507 F.2d 1024, 1026 (5th Cir. 1975); Goldwater v. Ginzburg, 414 F.2d 324, 339 (2d Cir. 1969), cert. denied, 396 U.S. 1049 (1970); Widener v. Pacific Gas \& Elec. Corp., 142 Cal. Rptr. 304, 314 (Cal. Ct. App. 1977), cert. denied, 436 U.S. 918 (1978); Fopay v. Noveroske, 334 N.E.2d 79, 88 (Ill. App. 1975).

${ }^{148}$ See Tavoulareas v. Piro, 817 F.2d 762, 797 (D.C. Cir.) (en banc) (stating that where there is overwhelming evidence that an article was published in good faith "the absence of deadline pressure is probative of nothing"), cert. denied, 484 U.S. 870 (1987).

149 See Simonson v. United Press Int'l, Inc., 500 F. Supp. 1261, 1269 (E.D. Wis. 1980), affd, 654 F.2d 478 (7th Cir. 1981); Times Publishing Co. v. Huffstetler, 409 So. 2d 112, 113 n.1 (Fla. Dist. Ct. App. 1982).

${ }^{150}$ See McCoy v. Hearst Corp., 727 P.2d 711, 728 (Cal. 1986) (holding that investigatory failures will not deprive a defamatory falsehood of its privileged status), cert. denied, 481 U.S. 1041 (1987); Wanless v. Rothballer, 503 N.E.2d 316, 322 (Ill. 1986) (stating that the failure to investigate "does not constitute actual malice if the defendants did not seriously doubt the truth of their assertions, and the failure to solicit plaintiff's reaction was nothing more than a failure to follow a course of investigation and verification"), cert. denied, 482 U.S. 929 (1987).

${ }^{151}$ See, e.g., Akins v. Altus Newspapers, Inc., 609 P.2d 1263, 1266-67 (Okla. 1977) (stating that reporter's failure to verify news story was part of "evidence of heedless conduct to show wanton indifference to [the] consequences" of publishing the story), cert. denied, 449 U.S. 1010 (1980). 
charges $^{152}$ or affirmative evidence of falsity, ${ }^{153}$ for example, may permit an inference of reckless disregard to be drawn from the defendant's failure to investigate. Whether such additional circumstances exist is not normally known at the beginning of litigation; the nature, scope, and results of the defendant's journalistic investigation are therefore usually discoverable on the theory that they may become part of the total corpus of circumstantial evidence from which the defendant's state of mind may be adduced.

Defendant's behavior after publication. The time of publication is the moment at which the defendant's knowledge or doubt is to be determined. ${ }^{154}$ Post-publication activities, however, may shed retrospective light on the defendant's state of mind at the time of publication and thus may be discoverable. On the one hand, prompt publication of a retraction is evidence tending to negate a finding of actual malice or an award of punitive damages. ${ }^{155}$ On the other hand, destruction of documents pending litigation supports an inference that the documents contained evidence tending to show reckless disregard of the truth. ${ }^{156}$

Credibility of defendant's informants. The Court has said that "recklessness may be found where there are obvious reasons to doubt the veracity of the informant or the accuracy of his reports." 157 It follows that plaintiff must be allowed to learn who the informant is, at least so long as he or she is not a confidential source. The plaintiff may be entitled to probe the defendant's relationship with the informant as a possible way of showing that

152 See St. Amant v. Thompson, 390 U.S. 727, 732 (1968) (stating that professions of good faith are unlikely to prevail "when the publisher's allegations are so inherently improbable that only a reckless man would have put them in circulation").

${ }^{153}$ See Nash v. Keene Publishing Corp., 498 A.2d 348, 355 (N.H. 1985) (stating that a failure to verify in the face of affirmative evidence of falsehood and inaccuracy could be sufficient evidence for a jury to find reckless disregard of the truth).

154 See Dupler v. Mansfield Journal, 413 N.E.2d 1187, 1193 (Ohio 1980), cert. denied, 452 U.S. 962 (1981); Taylor v. Miskovsky, 640 P.2d 959, 962 (Okla. 1981).

${ }^{155}$ See Kerwick v. Orange County Publications, 420 N.E.2d 970, 970 (N.Y. 1981) (stating that a promptly published retraction "might be considered evidence of lack of malice in certain instances"); see also Cape Publications, Inc. v. Teri's Health Studio, Inc., 385 So. 2d 188, 190 (Fla. Dist. Ct. App. 1980) (reversing an award of punitive damages where newspaper printed a full and fair retraction).

${ }^{156}$ See Brown \& Williamson Tobacco Corp. v. Jacobson, 827 F.2d 1119, 1134 (7th Cir. 1987) (holding that selective destruction of documents is "strong evidence of actual malice," and that a "court and a jury are entitled to presume that documents destroyed in bad faith while litigation is pending would be unfavorable to the party that has destroyed the documents"), cert. denied, 485 U.S. 993 (1988).

157 St. Amant v. Thompson, 390 U.S. 727, 732 (1968). 
the defendant may have doubted the source's credibility. This authorizes considerable intrusion into the defendant's relationship with sources. It invites the plaintiff to discover the informant's motivations for cooperating with the defendant, the defendant's previous dealings with the informant, and the defendant's policies regarding such relationships.

Confidential sources. The greatest intrusion into editorial processes comes when the defendant claims the defamatory material is based on information from a confidential source. For the reasons stated above, the plaintiff is entitled to show that the defendant had reason to doubt the source's credibility. In addition, "professions of good faith" are unlikely to prevail "where a story is fabricated by the defendant, is the product of his imagination, or is based wholly on an unverified anonymous telephone call. ${ }^{n 158}$ The plaintiff is therefore entitled to challenge the very existence of a source, confidential or otherwise. The plaintiff is entitled to pursue the suspicion that the claim of a confidential source conceals the absence of any independent basis for the defamatory accusation. ${ }^{159}$ This creates a conundrum: compelling disclosure of the source has the potential to chill an important newsgathering method, ${ }^{160}$ but refusing to do so may deprive the plaintiff of the opportunity to prove that the defamation was indeed a fabrication.

In all these ways, the actual malice standard requires intrusions, through discovery and at trial, into journalistic matters that are usually not called into question by the other issues in a libel case.

${ }^{158} \mathrm{Id}$.

159 See, e.g., Winegard v. Oxberger, 258 N.W.2d 847, 852 (Iowa 1977) (holding that where information sought by discovery is necessary or crucial to a cause of action, where other reasonable means of obtaining the information have been exhausted, and where the actions are not patently frivolous, a newsgatherer's privilege to withhold confidential information may be subordinated by the compelling state interest in the fair administration of justice), cert. denied, 436 U.S. 905 (1978).

${ }^{160}$ See Vince Blasi, The Newsman's Privilege: An Empirical Study, 70 MICH. L. REv. 229, 265-74 (1971). In its only consideration of this issue the Court declined to recognize a privilege against compelled disclosure in the cases before it, but a majority recognized the potential chill. See Branzburg v. Hayes, 408 U.S. 665, 710 (1972) (Powell, J., concurring) (arguing that the privilege should be judged by balancing vital constitutional and societal interests on a case-by-case basis). In dissent, Justice Douglas wrote that "[f]ear of disclosure will cause dissidents to communicate less openly to reporters," and that "fear of accountability will cause editors and critics to write with more restrained pens." Id. at 721 (Douglas, J., dissenting). In a separate dissent joined by Justices Brennan and Marshall, Justice Stewart wrote that the Court's holding would "needlessly discourage" First Amendment activity. See id. at 741 (Stewart, J., dissenting). 
Even if the standard were otherwise thought to be highly desirable, its intrusiveness into the relationships between reporters, editors, and sources would still cast doubts on its appropriateness.

\section{Diverting the Inquiry Away from Truth}

A plaintiff who files a libel suit against a media entity says, in effect, "that's a lie." In cases to which the actual malice standard applies, the alleged lie is, by hypothesis, about something in which the public has an interest. Often the "lie" is about matters in which the public has an interest of the highest order: the honesty of a public official, the fitness of a candidate for office, the conduct of a public figure. By filing the suit, the plaintiff publicly challenges the truth of the defendant's statements about a public matter.

The defendant's general denial puts truth at issue. Often, however, the truth or falsity of the statement gets little more attention for the remainder of the litigation. One explanation may be that " $[t]$ ruth is little used as a defense, though it would enable a decisive confrontation, because it may be very expensive to establish."161 There are at least two other reasons, however, why defendants do not often contest falsity. One is that sometimes it is futile to do so: plaintiffs probably do not normally sue over statements that are true, or they are at least more likely to sue over falsehoods. The second is that it is easier and less risky to invoke the actual malice standard. Falsity is a classic fact issue on which the defendant is unlikely to win summary judgment. Actual malice is nominally a fact issue also, but as explained above, the courts have largely taken it away from the jury and made it a basis for summary judgment.

Defending accusations of libel by contesting falsity is; therefore, more likely to require a full-blown trial. Although not necessarily more expensive or time-consuming than a defense on the actual malice ground, the defense of truth is risky. In England the jury may treat an unsuccessful defense of truth as a factor aggravating damages. ${ }^{162}$ No such instruction is permitted in the United States, but libel defense lawyers know that a similar danger exists. Jurors will not be oblivious to the additional travail suffered by the 1987).

161 Marc a. FrankiIn, Cases and Materials on MASS MEdia Law 137 (3d ed.

${ }^{162}$ See GATLEY ON LIBEL AND SLANDER $\$ 1330$ (Phillip Lewis ed., 8th ed. 1981). 
plaintiff as a result of the defendant's continued assertion of the truth of a statement the jury finds to be false.

By choosing to fight on the ground of actual malice rather than falsity, the defendant gets the best of both worlds. The defendant can formally deny the plaintiff's charge of falsity and maintain a "we-stand-by-our-story" posture without actually standing by the story. Even if it knows the story is false, the defendant can continue to proclaim the truth of the story while in fact building a defense around the actual malice standard. ${ }^{163}$ The availability of the actual malice defense not only deprives the plaintiff and the public of a judicial determination of the falsity issue, it can also deprive the plaintiff and public of an admission of falsity even in those cases where falsity is not seriously contested.

The public has a substantial interest in learning whether the statement published by the defendant and challenged by the plaintiff is true or false. It has very little interest in knowing whether the defendant entertained serious doubts about the truth of the statement. The actual malice standard, however, almost assures that the latter rather than the former will be the focus of the litigation.

\section{E. Prejudicing Defendants}

Because the actual malice standard turns the focus of the trial from the plaintiff's conduct to the defendant's, it may increase rather than decrease the threat to speech interests. Before New York Times $v$. Sullivan, the libel trial was often an ordeal for the plaintiff. The plaintiff's conduct and reputation were subjected to scrutiny on the issues of truth and mitigation of damages, respectively, and many victorious plaintiffs came away bloodied. ${ }^{164}$ In cases in which actual malice is the decisive issue, however, the blood is often the defendant's. There is little scrutiny of the plaintiff's conduct or reputation if falsity and damage are not seriously at issue. Instead, the focus is on the defendant's conduct. The kinds of evidence from

163 The only risk is the possibility that the defendant will have to pay the costs incurred by the plaintiff in proving falsity as a sanction for having failed to make a proper admission on that issue. See FED. R. Crv. P. 37(c).

${ }_{164}$ A famous example is Reynolds v. Pegler, 223 F.2d 429 (2d Cir.), cert. denied, 350 U.S. 846 (1955). The plaintiff, writer Quentin Reynolds, won $\$ 175,000$ in punitive damages but only one dollar in compensatory damages for a scurrilously defamatory attack; the defendants' trial strategy was to smear Reynolds with suggestions that he had associations with Communists. See id. at 435. 
which actual malice may be inferred invite searching inquiry into the defendant's practices, motives, and views. ${ }^{165}$ Trial lawyers love to paint disputes as contests between good and evil, and a trial in which actual malice is the controlling issue gives the skillful plaintiff's lawyer an unusual opportunity to portray the defendant as journalistic evil incarnate.

After a trial in which much of the time is spent dissecting evidence that the defendant knowingly lied or ignored its own serious doubts, one is not surprised at the jury's inclination to punish the defendant. It is not a trial in which the jury sees both parties as mortals with imperfections. It is one in which little attention is paid to the plaintiff, while the jury decides whether the defendant is a liar or merely incompetent.

In such a trial, if the jury finds actual malice, an award of punitive damages is almost a foregone conclusion. A jury could deny them on the ground that common law malice is not shown though actual malice is, but usually evidence of the latter makes it easy for the jury to find whatever additional level of culpability the state requires for an award of punitive damages. ${ }^{166}$ These dynamics create potent threats of punishment for unpopular journalism. The evidentiary focus created by the actual malice test gives the jury the motive to punish, and a finding that the test is met gives the jury the means. It is not surprising that jury awards are high in cases where actual malice is found. ${ }^{167}$

The purpose of the actual malice standard was to protect robust public discussion by reducing the extent to which the press censors itself due to the threat of litigation. It undoubtedly serves that purpose in various irrational ways-for example, by creating an exaggerated impression in the minds of some potential plaintiffs and lawyers that the press is impervious to public-plaintiff libel suits. The rule's actual effect on litigation, however, gives the press more cause for anxiety than comfort.

165 See supra text accompanying notes 137-60.

166 "While the required showing of common law malice has not been eliminated as an additional obstacle to punitive damage recovery if a state's underlying common law requires it, even in such cases proof of actual malice will almost always, as a practical matter, satisfy the common law standard of malice as well." Libel Tort Today, supra note $\mathbf{3}$, at 546.

${ }^{167}$ See Defamation Trials, Damage Awards and Appeals III: Two-Year Update (19841986), Libel Def. Resource Center Bull. No. 21 (LDRC, New York, N.X.), Fall 1987, at 20, tbl. 13-e. 


\section{The Reputational ANd Social Costs}

Even if the actual malice standard were an efficient and effective way of protecting the press and other speakers, it could not be pronounced a success without taking into account the price it exacts from other values. One of those, the cost to personal reputation, is obvious. The very purpose of the standard is to deny a remedy to some whose reputations have been harmed by defamatory falsehoods. There are at least two other exactions, less obvious but perhaps even more costly to society. One is the effect on the political process, and the other is the effect on public discourse generally.

\section{A. Reputational Costs}

By design, the actual malice standard deprives public figures and public officials of any legal remedy for most defamatory falsehoods. As explained above, ${ }^{168}$ public officials are not limited to elected officials, or even to those we would normally think of as officials, but include ordinary governmental employees such as police officers. The public-figure category includes celebrities, persons who seek to influence the outcome of public controversies, and some who are involuntarily caught up in public events or issues. The category is not restricted to national celebrities or national controversies. ${ }^{169}$ As a result, millions of Americans are likely to be classified as public officials or public figures when they are defamed.

The actual malice standard also denies any remedy to many who are neither public officials nor public figures. Anyone who is defamed in connection with a matter of public concern must prove actual malice if he or she cannot prove actual injury. This limitation rarely bars suit, because actual injury can be established by proof of emotional distress, which few defamation plaintiffs lack. ${ }^{170}$ But

${ }^{168}$ See supra text accompanying notes $47-48$.

${ }^{169}$ See supra text accompanying notes $49-55$.

${ }^{170}$ See Time, Inc. v. Firestone, 424 U.S. 448, 460 (1976) (stating that states may base defamation awards on elements other than injury to reputation, including "personal humiliation and mental anguish and suffering" (quoting Gertz v. Robert Welch, Inc., 418 U.S. 323, 350 (1974))). State law sometimes requires plaintiffs to show more than emotional distress. See, e.g., Gobin v. Globe Publishing Co., 649 P.2d 1239, 1244 (Kan. 1982) (agreeing with New York rule requiring harm to reputation before claim of mental anguish can be compensable). Generally, however, no such requirement exists. In Hearst Corp. v. Hughes, 466 A.2d 486, 489 (Md. 1983), for 
it often denies any remedy as a practical matter, because the plaintiff's provable actual injury is not large enough to induce a lawyer to take the case on a contingency-fee basis. ${ }^{171}$ Many, if not most, private plaintiffs cannot afford to litigate unless they can recover presumed damages, and those damages are unavailable unless actual malice is shown.

The actual malice rule, therefore, leaves vast numbers of people-perhaps most of the victims of media defamation-with no legal remedy for damage to reputation. The cost to the victims, in terms of anguish and reputational harm, is incalculable. There is room, of course, for much disagreement about the law's ability to identify and quantify injuries of this sort. Because of these doubts, the law no longer provides a remedy for some of the wrongs that produce these injuries, such as seduction and breach of promise to marry. ${ }^{172}$ But for many centuries and in most of the civilizations of the world, the injuries caused by defamation were thought to be harms for which the law can and should provide remedies. Eloquent reasons for this virtually universal protection of reputation have been advanced throughout history, ${ }^{173}$ but the contemporary consensus is captured in Justice Stewart's classic explanation: "The right of a man to the protection of his own reputation from unjustified invasion and wrongful hurt reflects no more than our basic concept of the essential dignity and worth of every human being-a concept at the root of any decent system of ordered liberty." 174 It is probably safe to say that no major legal system

example, the court declined to require harm to reputation before compensatory damages could be awarded. The court stated that if victims of defamation "can convince a trier of fact that their emotional distress is genuine and can prove the other common law and constitutionally required elements of a negligent defamation case, we see no social purpose to be served by requiring the plaintiff additionally to prove actual impairment of reputation." Id. at 495.

171 The available data indicate that most plaintiffs engage their lawyers on a contingent fee basis. See LIBEL LAW AND THE PREss, supra note 3, at 69.

172 The demise of remedies for these kinds of injuries is described in W. PAGE KeEtoN ET AL., PROSSER AND KeETON ON THE LAW OF TORTS $\$ 124$, at 930 (5th ed. 1984). Some courts have recognized actions for negligent infliction of emotional distress under various circumstances, but there is no general principle authorizing recovery for negligently inflicted distress. See Michele A. Scott, Note, Proving Beyond a Reasonable Doubt: The Negligent Infliction of Emotional Distress, 11 CARDOZO L. REV 235, 237-44 (1989) (discussing various types of actions recognized in different jurisdictions).

${ }^{173}$ Some of the more famous bits of rhetoric are quoted-and perceptively examined-in Smolla, Let the Author Beware, supra note 3, at 14-15 \& n.84.

${ }^{174}$ Rosenblatt v. Baer, 383 U.S. 75, 92 (1966) (Stewart, J., concurring). 
in the world provides as little protection for reputation as the United States now provides.

The Supreme Court has never candidly faced up to the reputational costs exacted by the actual malice rule. Instead, the Court has tried to minimize the sacrifice of reputations by unconvincing rationalizations, the two most prominent being the self-help and waiver rationalizations. ${ }^{175}$

The self-help rationalization contends that public plaintiffs are less vulnerable to reputational harm than private persons, because they usually have more access to media and therefore more opportunity to protect their reputations through self-help. Justice Brennan demolished this argument in a passage in Rosenbloom $v$. Metromedia, Inc. ${ }^{176}$ that deserves full quotation:

While the argument that public figures need less protection because they can command media attention to counter criticism may be true for some very prominent people, even then it is the rare case where the denial overtakes the original charge. Denials, retractions, and corrections are not "hot" news, and rarely receive the prominence of the original story. When the public official or public figure is a minor functionary, or has left the position that put him in the public eye ... the argument loses all of its force. In the vast majority of libels involving public officials or public figures, the ability to respond through the media will depend on the same complex factor on which the ability of a private individual depends: the unpredictable event of the media's continuing interest in the story. Thus the unproved, and highly improbable, generalization that an as yet undefined class of "public figures" involved in matters of public concern will be better able to respond through the media than private individuals also involved in such matters seems too insubstantial a reed on which to rest a constitutional distinction. ${ }^{177}$

${ }^{175}$ In the course of explaining why the Court declined to impose on private plaintiffs the same burdens it had imposed on public officials and public figures, Justice Powell described these rationales and asserted reasons why they were not applicable to private persons. See Gertz v. Robert Welch, Inc., 418 U.S. 323, 344-45 (1974). The Court had not previously relied on these arguments as reasons for imposing greater burdens on public plaintiffs, however.

176403 U.S. 29 (1971).

${ }^{177}$ Id. at 46-47 (plurality opinion by Brennan, J.) (citation omitted). Adopting the self-help argument in Gertz, despite Justice Brennan's criticism, Justice Powell responded rather lamely that "the fact that the self-help remedy of rebuttal, standing alone, is inadequate to its task does not mean that it is irrelevant to our inquiry." 418 U.S. at 344 n.9. 
The waiver argument as articulated by Justice Powell is as unpersuasive as the self-help argument:

[T] here is a compelling normative consideration underlying the distinction between public and private defamation plaintiffs. An individual who decides to seek governmental office must accept certain necessary consequences of that involvement in public affairs. He runs the risk of closer public scrutiny than might otherwise be the case. ... Those classed as public figures stand in a similar position. Hypothetically, it may be possible for someone to become a public figure through no purposeful action of his own, but the instances of truly involuntary public figures must be exceedingly rare. For the most part those who attain this status have assumed roles of especial prominence in the affairs of society. Some occupy positions of such persuasive power and influence that they are deemed public figures for all purposes. More commonly, those classed as public figures have thrust themselves to the forefront of particular public controversies in order to influence the resolution of the issues involved. In either event, they invite attention and comment. ${ }^{178}$

This argument is riddled with fallacies. First, the idea that a public official "runs the risk of closer public scrutiny" hardly compels the conclusion that he or she must be left without remedy when the scrutiny is actually defamatory falsehood. Logic supports the opposite conclusion equally well: because the risk of close public scrutiny-and therefore defamation-is greater, the law should be more protective of the reputation interest. ${ }^{179}$

Second, the public official classification is by no means limited to those who "seek governmental office" in the usual understanding of that phrase. For example, police officers are almost invariably classed as public officials, no matter how low their rank. ${ }^{180}$ Whatever validity the waiver argument might have for those who seek elective office, it has little for the individual who is a "public

178 Gertz, 418 U.S. at 344-45.

${ }^{179}$ In many states, the murder of a law enforcement officer is a more serious offense than the murder of a private citizen. This is not because officers' lives are more valuable, but because they are exposed to more risk. In view of this increased risk, the criminal law attempts to provide more protection by increasing the legal deterrent. I am not arguing that this comparison proves that public plaintiffs should receive more protection in libel than private plaintiffs; only that logic does not require that public plaintiffs receive less.

180 Cases examining what groups of people are classified as public officials are collected in McCrory et al., supra note 80, at 516-27. 
official" simply because he or she holds a position of some responsibility in some unit of government.

Third, many public figures are not people who have thrust themselves to the forefront of public controversies. Rather, they are people who have been unusually successful in their careers-whether in business, the arts, sports, entertainment, or some other profession. Johnny Carson is a public figure because he is a popular television entertainer, not because he seeks to influence public affairs. ${ }^{181}$ His wife is a public figure simply because she is married to him. ${ }^{182}$ A professional football player can become a public figure by being involved in a highly publicized player trade. ${ }^{183}$ A belly dancer may be a public figure because she welcomed publicity about her performances. ${ }^{184}$ These people have made no choice to sacrifice reputation in exchange for power and influence; indeed, those attributes sometimes seem to accrue in largest measure to those who seek them least. Power and influence, along with fame and wealth, simply tend to follow success. ${ }^{185}$

Fourth, and most importantly, the waiver argument is circular. If those who seek public office or seek to influence the outcome of public controversies waive some portion of reputational protection by doing so, it is only because the law says so. It cannot explain why the law says so. Public figures do not choose to forego remedies for defamation. True, they may know that they are more likely to be discussed and hence to be defamed, but as suggested above, that need not weaken their claim to the law's protection.

Although the Court's rationalizations for minimizing the reputational costs of the actual malice rule are unconvincing, the disregard of these costs has not been widely criticized. Perhaps this reflects a sense that the Court is right even if its reasons are unpersuasive. If one believes that reputational costs are in fact negligible, then the lack of satisfactory reasons for ignoring them is less troublesome.

The unarticulated reason may be a belief that public plaintiffs are intrinsically less worthy of protection than others. Perhaps the

181 See Carson v. Allied News Co., 529 F.2d 206, 209-10 (7th Cir. 1976).

182 Id. at 210.

${ }^{183}$ See Chuy v. Philadelphia Eagles Football Club, 595 F.2d 1265, 1280 (3rd Cir. 1979) (en banc).

184 See James v. Gannett Co., 353 N.E.2d 834, 840 (N.Y. 1976).

185 See Schauer, supra note 3, at 914-21 (arguing that the Supreme Court's reasons for extending the actual malice rule from public officials to public figures have little application to many of those now swept within the category of public figures). 
real "compelling normative consideration underlying the distinction between public and private defamation plaintiffs" ${ }^{186}$ is a perception that public officials and public figures deserve to be defamed. Perhaps some people believe that public officials and candidates, as a class, are more venal than the rest of us, or that they care less about their reputations. Maybe it is thought that they deserve to "die by the sword" because they live by it-that they probably destroyed or damaged reputations of others in their own climb to prominence, and +2 . efore deserve little sympathy when they fall prey to similar tactics. ${ }^{187}$ There may be a feeling that a license to defame those who achieve prominence in public life is a fair price to exact as a cost of success: just as the wealthy should pay more in taxes, the famous should give up more in the way of reputation. ${ }^{188}$ Maybe the idea is more explicitly political: that denying the prominent some measure of the usual protection for reputation is a useful counterweight to the power-social, political, and economic-they otherwise enjoy.

Some of these perceptions would be applicable to public figures as well as public officials. A steady diet of disclosures about the personal, moral, and financial peccadillos of entertainment stars, business leaders, evangelists, sports heroes, and other celebrities may persuade some that these people too are more venal than the rest of us, or less concerned about reputation. One may think that the adulation they receive is often undeserved and that undeserved condemnation therefore is no great injustice. Because public figures enjoy a great deal of power as a result of the favorable attention of the press and public, fairness might require a counterbalance to this heightened power by allowing the press and public the right to scrutinize and criticize them. ${ }^{189}$

186 Gertz v. Robert Welch, Inc., 418 U.S. 323, 344 (1974).

187 See Smolla, Let the Author Beware, supra note 3, at 2 (noting that many defamation plaintiffs, including public officials, have used media attention to their benefit in the past).

188 This view apparently is not shared by the general public, however. According to one survey, three-fourths of the public believe libel laws ought to be the same for public officials as for private citizens, and two-thirds believe public officials should be able to recover for defamation even if defendants believed the report was true at the time of publication. See TIMES-MIRROR CENTER FOR THE PEOPLE AND THE PREss, THE PEOPLE AND THE PRESS-PART I: ATTTTUDES TOWARD THE NEWS MEDIA, 35-36 (Gallup poll conducted in January 1986), reported in LARRY J. SABATO, FEEDING FRENZY: HOW ATTACK JOURNALISM HAS TRANSFORMED AMERICAN POLITICS 202 (1991).

${ }^{189}$ One version of this idea is discussed in Neal Gabler, The Gossip of Mount Olympus, N.Y. TIMES, Apr. 17, 1991, at A23. 
Each of these views undoubtedly has some subscribers. On balance, however, I reject the proposition that public plaintiffs deserve less protection than others. I doubt that as a class, public plaintiffs are more venal. Even if they are, their venality can be taken into account more fairly by evaluating their transgressions in individual cases.

The rationale that public plaintiffs should have to suffer adverse publicity because they have benefitted from good publicity, or because they have harmed reputations on their way to the top, is inapplicable to many public plaintiffs. Many lesser public figures and lower level public officials have done neither. Even among the most prominent elected officials and celebrities, not all have lived by the sword of defamation.

The view that defamation is a just counterbalance to power should at least be critically examined. Those holding this view should be required to explain why other limitations on power are inadequate. If we accept that argument, we should decide openly how much reputational protection must be sacrificed to effectively control the power, instead of pretending that the powerful have waived their right to reputational protection.

The courts have never espoused the idea that the falsehoods protected by the actual malice rule cause no harm, or that those harmed are unworthy of a remedy. ${ }^{190}$ But neither have the courts forthrightly acknowledged that the rule exacts a serious sacrifice in the form of uncompensated injury to reputation.

All gossip is predicated on the idea that there is a world from which we have been excluded. By collecting gossipy anecdotes, we invade the celebrity's world. By shaping narratives around their pecadilloes [sic], we assert our priority over them. It's the prose version of the strip search.

Of course, gossips receive nothing but opprobrium .... [But i]n a democratic society, what may seem like voyeurism may actually be a healthy activity not only because it provides us with a means of framing our values but because it channels our vengeance against the prevailing elites and knocks them down to size.

Id.

190 See, e.g., Dun \& Bradstreet, Inc. v. Greenmoss Builders, 472 U.S. 749, 756 (1985) (noting that the level of constitutional protection for defamation depends on both the strength of the state interests in protecting reputation and the concerns of the First Amendment). 


\section{B. Social Costs}

The reputational costs described above are primarily private costs borne by the individuals who are left without a remedy for their reputational injuries. In addition to those costs, the actual malice rule also exacts a price from the society at large. It imposes costs on public life, by which I mean not only politics, but also cultural, religious, educational, and business life.

The actual malice rule obviously deters participation in public life. ${ }^{191}$ No rational person can fail to take into account the reputational consequences of this rule when deciding whether to run for public office. Though the full effect of the rule and all its accouterments is probably understood by very few lawyers, let alone nonlawyers, virtually all potential candidates must have some awareness that it is difficult for a public official or political candidate to recover for defamation. ${ }^{192}$

Some of this deterrence may be salutary. To the extent that those deterred fear disclosure of their future (or past) misdeeds in office, the rule is beneficial. But it undoubtedly deters others who do not fear disclosure of misdeeds, but do fear false accusations about matters in which they are blameless. ${ }^{193}$ Even those so confident of their reputations that they fear no harm from falsehoods may be deterred from public life simply because they have no stomach for a life in which they know they and their families will have to endure scurrilous aspersions. Defending a state law precursor of the actual malice rule in 1908, the Kansas Supreme Court said "here at least men of unimpeachable character from all political parties continually present themselves as candidates in sufficient numbers to fill the public offices and manage the public institutions, and the conduct of the press is as honest, clean, and free from abuse as it is in states where the narrow view of privilege obtains."194 It is difficult to be so sanguine today about the quality of people who present themselves for public office.

191 "Simply put, the price of power has been raised dramatically, far too high for many outstanding potential officeholders." SABATO, supra note 188, at 211 (footnote omitted).

192 The rule is sufficiently, recognized in the popular culture to serve as the premise for a movie, see ABSENCE OF MALICE (Columbia Pictures Indus. 1981), starring Paul Newman and Sally Field, and the title of a popular book, see RENATA ADLER, RECKLESS DISREGARD (1986).

${ }^{193}$ Worse, perhaps, is the fear of opportunistic exploitation of the ordinary sins that accumulate in most lives.

${ }^{194}$ Coleman v. MacLennan, 98 P. 281, 289 (Kan. 1908). 
The constitutional rules also create risks for other forms of citizen participation in public matters-from the local PTA to religious controversies to the abortion controversy and other great issues of the day. Although not everyone may realize that the actual malice rule also applies to public figures, here, too, any observant person can see that those who participate in public matters seem to receive little protection from the law of defamation.

The rule's deterrent effect on participation in public life has a corollary: those who choose to participate despite the risk are likely to be different from those who are deterred from participation. Vulnerability to certain types of defamation often depends on the victim's generation, life experiences, profession, or ethnic background. A false accusation may seem plausible because it fits a stereotype: an accusation of drug use directed at someone who grew up in the ghetto, a charge of sexual promiscuity against someone who was a college student in the late 1960's, a rumor of organized crime connections directed at a person with an Italian surname, an implication of dishonesty directed at someone employed in the legal gambling industry. Some people may avoid public life simply because they fit a high-risk stereotype. Those who take the risks of participation may be people who care less about their reputations than others do-people who might say "I don't care what they say about me as long as they spell my name right." Personality types who relish the combat of personal attack and counterattack may be attracted to public life while other types are repelled. ${ }^{195}$

These corollary effects are most pronounced in politics-both electoral and issue politics-but they are also felt in other fields of public life. In some aspects of show business, for example, a thick skin is a virtual necessity and a willingness to endure or even cultivate the most scurrilous publicity can be an asset. A talented actor or popular musician who lacks a tolerance for scandal may be at a competitive disadvantage. A person who is deeply disturbed by defamatory falsehoods may find it hard to survive at the highest and most visible levels of sports, business, religion, or education.

These effects are all speculative, but so is the "chilling effect" on speech that the actual malice rule exists to prevent. The constitutional law of libel rests on the unproven assumption that failure to

195 "If we tell people there's to be absolutely nothing private left to them, then we will attract to public office only those most brazen, least sensitive personalities." SABATO, supra note 188, at 212 (quoting New York Times columnist Anthony Lewis). 
protect those who report on public life will tend to deter news reporting and commentary. This proposition has never been demonstrated empirically, but it is an intuition no one seriously challenges. ${ }^{196}$ It is no more compelling intuitively, however, than the assumption that failure to protect those who participate in public life will deter some persons from participating. Most of the important choices in law, as in life, have to be made on the basis of unprovable assumptions about human behavior. I do not doubt the existence of the "chilling effect" or deprecate its importance merely because it has not been empirically confirmed. Neither can we afford to ignore the deterrent effects of the actual malice rule for want of empirical proof.

The actual malice rule has an effect not only on participation in, but also on discussion about, public life. The journalistic commitment to substantive coverage of issues is always in some competition with market pressures to serve the public appetite for scandal. One of the challenges of journalism is to engage the public's attention in substantive matters against the competition of the titillating. ${ }^{197}$ Though scandal may be difficult to uncover, it is comparatively easy to present. A world that can be explained by mendacity, perfidy, or venality is easier to understand than one that is a product of historical, economic, demographic, social, and scientific forces, as well as human failings. The former view tends to be self-reinforcing; the more scandal we see, the more plausible it seems that scandal explains our situation. ${ }^{198}$ The latter view, on the other

196 The best analysis of the assumptions underlying the "chilling effect" concept is Frederick Schauer, Fear, Risk and the First Amendment: Unraveling the "Chilling Effect, 58 B.U. L. REV. 685 (1978).

197 The inequality of the contest is illustrated in a journalism review analysis of the media treatment of two news events in April, 1991. A biography appeared containing salacious accusations about Nancy Reagan, and a few days later a former Carter administration official made public allegations that the Reagan campaign had made a deal with Iranian Revolutionaries to delay the release of American hostages until after Reagan's inauguration. The allegations about Nancy Reagan were reported in major stories on the evening news programs of $A B C, N B C$, and CBS, on page one of the New York Times, and in cover stories in Time and Newsweek. The allegations about the presidential campaign appeared on page 10 of the New York Times, did not make the evening newscasts of any of the three networks, and appeared in Time and Newsweek only several weeks later in noncover stories. See Julie Cohen, Who Will Unwrap the October Surprise?, Colum. JOURNALISM REv., Sept./Oct. 1991, at 32.

${ }^{198}$ In news coverage of charges against public officials and candidates, "the approach usually taken by journalists is clear: a repetitive, disproportionate stress on scandal, a 'more of the same' theme, a 'what can you expect from politicians' tone that deepens, extends, and reinforces the enduring public suspicion of all things political." SABATO, supra note 188, at 207 (footnote omitted). 
hand, tends to be confusing and inconsistent; there is always disagreement as to what the forces are, let alone what their significance may be. Evaluating these forces requires more mental effort from the reader or viewer. For the journalist, uncovering scandal is likely to seem a surer route to recognition and advancement than the tedious and incremental process of identifying and explaining the other forces that shape the world. ${ }^{199}$

The journalism of scandal therefore enjoys a considerable advantage over its alternatives, even without help from the law. The actual malice rule reinforces that advantage by eliminating most of the risks associated with the journalism of scandal, at least when it is directed at public officials or public figures. It thus throws the weight of the law on the side of the public appetite for scandal. This tilt encourages even those in the press who would prefer another direction to gravitate toward scandal.

These two effects-skewing the personality profile of those who are willing to participate in public life and encouraging journalistic preoccupation with scandal-exalt a politics of scandal. In election campaigns, voting records and positions on issues cannot successfully compete for voter attention against accusations of adultery, larceny, and corruption. The experience and qualifications of nominees to high judicial or executive office are hard to keep in focus when the nominee's enemies are free to offer more lurid images without much need to worry about whether they are true or false. ${ }^{200}$ The result is a dynamic that debases politics and public life. ${ }^{201}$ As Justice Stewart observed, "the poisonous atmosphere of the easy lie can infect and degrade a whole society."202

The other major social cost of the actual malice rule is its deprecation of truth in public discourse. The rule's very purpose is to protect the dissemination of falsehoods. As a consequence, "the stream of information about public officials and public affairs

199 Cf. Steve Weinberg, The Kitty Kelley Syndrome, Colum. JouRnalism REV., July/ Aug. 1991, at 36, 37 (noting that author of scandalous celebrity biographies enjoyed continuing fame and financial success despite documented history of inaccuracy).

200 For the most recent example of the power of the lurid, compare the attention paid to the first round of Senate Judiciary Committee hearings on the nomination of Justice Thomas, which focused on his executive and judicial record, with that paid to the second round, which focused on an allegation of sexual harassment.

${ }^{201}$ See Howard Rosenberg, NBC News: How Mighty Have Fallen, L.A. TIMEs, May 1, 1991, at F1 (concluding that the accusations made against potential presidential candidate Charles Robb in a network news program aired during television ratings sweeps were largely unsubstantiated).

${ }^{202}$ Rosenblatt v. Baer, 383 U.S. 75, 94 (1966) (Stewart, J. concurring). 
is polluted and often remains polluted by false information." ${ }^{203}$ I do not doubt that at times falsehood must be protected, even defamatory falsehood. Indeed, I fully subscribe to the Court's determination that defamatory falsehoods must be protected unless they can be proved false. But we must not forget that these concessions are made to facilitate the pursuit of truth. The utility of protecting some falsehood in the course of that pursuit must always be carefully weighed against the ultimate cost to the truthseeking enterprise. ${ }^{204}$

To the extent that the actual malice rule protects falsehood, it also undermines the credibility of the press. If the public knows the press is legally accountable for defamatory falsehoods, it may infer that the press must have some evidence that a defamatory accusation is true. A reader or viewer who understands the actual malice rule can only infer that the press believes the victim will not be able to prove with convincing clarity that the publisher had serious doubts as to the truth of the accusation. Few readers and viewers are that sophisticated, of course, but surely many sense in a general way that the law imposes only rather loose constraints of truth on the press's discussion of public people. To that extent, the press is as much a victim as a beneficiary of the actual malice rule. The rule devalues the currency of public information, and the strength of that currency is ultimately more important to the press than to any one else. ${ }^{205}$

How can the actual malice rule be underprotective of both speech and reputation? At least part of the answer lies in an information gap arising from the nature of the actual malice

${ }^{203}$ Dun \& Bradstreet, Inc. v. Greenmoss Builders, 472 U.S. 749, 769 (1985) (White, J., concurring in the judgment).

204 As Justice White wrote:

Criticism and assessment of the performance of public officials and of government in general are not subject to penalties imposed by law. But these First Amendment values are not at all served by circulating false statements of fact about public officials. On the contrary, erroneous information frustrates these values.

Id. at 767.

${ }^{205}$ As my colleague L.A. Powe, Jr. puts it: "Like the Holy Roman Empire which was neither Holy nor Roman nor an Empire, the constitutional rules of libel protect neither reputation nor the press nor the public's interest in receiving accurate information." L.A. Powe, Mass Communications and the First Amendment: An Overview, 55 LAW \& CONTEMP. PROBS. (forthcoming 1992) (manuscript at 12 , on file with author). 
requirement. $^{206}$ Actual malice is a subjective state-of-mind test: whether the defendant had serious doubts about the truth of the accusation. When the victim is deciding whether to sue, he or she usually has little information about this issue. Moreover, the victim cannot gain this information quickly once litigation begins. Defendant's pleadings normally deny the existence of actual malice in some conclusory fashion, and defendant's answers to interrogatories are unlikely to contain any more on this issue than self-serving declarations that the defendant believed the publication to be true. Only after more thorough discovery, with the certainty of expense and the potential for intrusion into editorial processes, is the plaintiff likely to be able to make any informed judgment as to the likelihood of proving actual malice.

In cases in which actual malice is an issue, plaintiffs often have no way of knowing whether they have any chance of succeeding until discovery is completed. They must therefore put themselves and defendants to considerable expense and inconvenience before they have the information needed to make rational litigation decisions. It is not surprising, then, if they tend to overestimate their chances of succeeding; ${ }^{207}$ given a choice between an uninformed decision to sue and an equally uninformed decision to desist, plaintiffs understandably might choose to err on the side of seeking redress. ${ }^{208}$

To the extent that the actual malice rule forces plaintiffs to make their litigation decisions without adequate information about the decisive issue in the case, it almost guarantees that hopeless. cases will be filed and litigated at least through discovery. This result burdens speech without any commensurate benefit to reputation and helps explain why the actual malice rule does not add to the field of free speech all that it subtracts from the protection of individual reputation. ${ }^{209}$

206 This explanation was first suggested to me by my colleague, Cynthia Estlund.

${ }^{207}$ See, e.g., George L. Priest \& Benjamin Klein, The Selection of Disputes for Litigation, 13 J. LEGAL STUD. 1, 4-6 (1984) (contending that imperfect information and unwarranted optimism are litigation stimuli throughout the law).

${ }^{208}$ No doubt some plaintiffs err in the other direction-that is, they refrain from suing for defamatory falsehoods because they are unaware of the evidence that would enable them to prove actual malice and do not litigate to discover it because of the perceived difficulties of meeting that standard. In these instances, the standard underprotects reputation and overprotects speech.

${ }^{209}$ Other possible explanations might be that (1) victims react to defamation emotionally rather than rationally, suing when they know (or should know) that they have no chance of winning, or (2) defendants react irrationally, incurring costs (and 


\section{OPPORTUNITIES FOR REFORM}

\section{A. Reconsidering the Constitutional Law}

Media discontent with the existing system of libel law could be alleviated by changes consistent with existing constitutional rulesfor example, by abolishing the tort altogether or by further restricting the cause of action to eliminate large recoveries or reduce litigation costs. The need to reduce burdens on speech, though, is only one side of the case for libel law reform; the present system's evisceration of remedies for victims of defamation is equally unsatisfactory. Victims' discontent with the system can be addressed only by changing some of the constitutional rules or by finding better remedies consistent with the existing rules. A reform agenda should not foreclose either possibility.

First, we should assume that if the remedies are less burdensome on speech, the constitutional limitations can be less burdensome on plaintiffs. Media partisans sometimes declaim as if they believe no scheme of libel law can be constitutional unless it retains all the rules that have evolved from New York Times v. Sullivan. ${ }^{210}$ Neither the logic nor the history of the rules supports that proposition, however. The rules represent the Court's "continuing effort to define the proper accommodation" between "the need for a vigorous and uninhibited press and the legitimate interest in redressing wrongful injury." 211 The logic of balancing implies that when the weight on one side changes, an adjustment on the other side may be appropriate. The Court made just such an adjustment in private-plaintiff cases, holding that actual malice need not be required when recovery is confined to actual injury, though it must be shown if punitive or presumed damages are sought. ${ }^{212}$

New York Times $v$. Sullivan was a response to libel law as it existed in 1964, when the press enjoyed far less protection than it has today. One of the rationales for the actual malice rule was the belief that under then-existing law, speech would be chilled "even

thus burdening speech) in amounts greater than would be necessary to pay for the reputational harm they have caused.

${ }^{210}$ See, e.g., Report of the Libel Defense Resource Center on the [Uniform] Defamation Act, (June 25, 1990) (unpublished manuscript on file with the author). This report is a critique of the model defamation act proposed to the National Conference of Commissioners on Uniform State Laws on July 13-20, 1990, a predecessor of the PROPOSED DEFAMATION ACr, supra note 7.

211 Gertz v. Robert Welch, Inc., 418 U.S. 323, 342 (1974).

212 See id. at 348-50. 
though it is believed to be true and even though it is in fact true, because of doubt whether it can be proved in court or fear of the expense of having to do so." ${ }^{213}$ Now that plaintiffs must prove falsity, this concern is alleviated. Moreover, when New York Times was decided, there were no constitutional rules protecting nonfactual expressions or neutral reportage and no authorization of judicial activism on the issues of defamatory meaning, substantial truth, and colloquium. ${ }^{214}$ Quite apart from the actual malice rule, the press today enjoys far more protection than it did in 1964. It is nonsense to insist that New York Times, the Court's first effort to protect the press, must continue to be read as if the Court has done nothing to preserve freedom of the press since then.

Second, we should recognize that the present constitutional restrictions are not all mutually dependent. The rules on nonfactual expression, neutral reportage, and falsity can stand quite independently of the actual malice rule (and of each other). The relationships among independent review and clear and convincing proof, on the one hand, and actual malice, substantial truth, colloquium, and defamatory meaning, on the other, are intertwined, but perhaps not inextricably so. Aggressive judicial review developed largely in the context of actual malice, but now that the practice is established, judges could continue to employ it in connection with other issues even if the actual malice rule were abolished. Likewise, even though convincing clarity originated as the standard of proof for actual malice, it could easily be applied to other issues.

Third, the actual malice rule itself should be reconsidered. Although it was originally the centerpiece of constitutional libel law, there are now many other sources of protection. Moreover, it is now clear that however useful that rule may be, the costs it imposes on reputation, on public life, and on the press are substantial. The Court has shown remarkable fealty to the rule and is probably unlikely to abolish it outright. But its applicability to celebrities (and perhaps other public figures who cannot be analogized to public officials) may well be ripe for reconsideration.

Fourth, the Court should encourage judges to decide certain crucial issues before trial. Defamatory meaning, colloquium, and substantial truth are normally treated as jury issues requiring trial, but the Court has already subordinated the jury's role by allowing

${ }^{213}$ New York Times v. Sullivan, 376 U.S. 254, 279 (1964).

214 See supra notes 23-36 \& 68-70 and accompanying text. 
independent review of those issues after trial. If the jury's finding is not to be respected anyway, it is more sensible to allow judges to make the determination at the beginning of litigation than to require the parties to engage in years of discovery, litigation, and appeals, only to have an appellate court eventually dispose of the case on an issue that could have been decided on the pleadings or with minimal discovery.

Early decision should also be encouraged when the statement sued upon is claimed to be nonfactual. Although the Gourt was right to stop the unprincipled growth of the opinion defense, it was equally correct in recognizing that there are some statements which, though capable of defamatory interpretation, are not sufficiently factual to provide the basis for a libel claim. The Court should make it clear that judges have wide latitude to decide that matterand other issues relating to defamatory meaning, colloquium, and substantial truth-on a motion to dismiss or an early summary judgment motion.

Finally, the Court should rethink the roles of judge and jury. The constitutional libel law reforms of the past quarter century have been effective in protecting speech primarily because they have transferred a great deal of power from juries to judges. The actual malice rule, by itself, would have effected comparatively little change in the law of defamation; it would have merely created another issue for the jury. Actual malice has become an effective obstacle to recovery only because of the ancillary rules of clear and convincing proof and independent review that enable judges to take matters out of the jury's hands altogether. Allowing judges to decide who is a public figure and what types of speech may be actionable has further diminished the jury's role. Since independent review occurs only when the jury finds for the plaintiff, this shift of power is a one-way movement that benefits defendants exclusively.

Historically, this denial of jury power in the name of the First Amendment is ironic, to say the least. Libel law reformers of the eighteenth century believed that the salvation of free speech lay in the transfer of power to juries. They saw the state and its judges as the principal threat to free speech, so they fought to give juries power to determine the defamatory tendencies of words, exonerate defendants upon proof of truth, and judge the law as well as the facts by giving general verdicts. ${ }^{215}$ It is understandable that the 
Court has chosen not to announce that it is rejecting the assumptions of the Framers of the First Amendment. That it is doing so must be understood, however, if we are to appreciate fully what is occurring in the law of defamation.

Ironic as it may be, the shift of power away from juries is unquestionably necessary. Today it is the prejudice and profligacy of juries that threaten free speech, not the criminal law of libel. For whatever reasons, the media today are so out of favor with the general populace that reliance on juries as reliable protectors of freedom of the press would be nostalgic nonsense. On the whole, judges are more sympathetic to speech interests than jurors and more sensitive to subtle threats against those interests. We may as well be candid: constitutional protection of speech against the chilling effects of libel consists primarily of rules encouraging judges to decide factual matters that previously were left to juries. Judges now hold the ultimate power to deny recovery for want of clear and convincing proof of actual malice, because the statement is not sufficiently factual, false, or defamatory, or because it does not sufficiently identify the plaintiff.

Having abandoned the fact of jury hegemony in libel, we should now abandon the fiction of it. Allowing judges to make these determinations early in the litigation avoids the expense and delay of unnecessary jury trials. These benefits are lost when judges make their decisive judgments only after a jury has made its own determination of the matter. We cling to the notion that the judge's role, though "independent" of the jury, is still one of "review." In some cases, judges convert the power of independent review into a power of preliminary disposition by fudging on the usual summary judgment standards. ${ }^{216}$ In most cases, however, to preserve an illusion of deference to the jury, judges exercise their power only at the end of litigation. Even though the eventual holding is that no liability can be constitutionally imposed whatever the jury may find, that judgment is not made until after jury trial.

JoHn Peter Zenger 23 (Stanley Katz ed., 1963) (describing Alexander Hamilton's defense of Zenger, in which he argued not only that a libel case was for a jury to decide, but also that "truth was a defense against an accusation of libel, and that the jury had the right to return a general verdict where law and fact were intertwined"). See generally LeONARD W. LEVY, EMERGENCE OF A FREE PRESS 128-33 (1985) (discussing the Zenger case and its influence on contemporary understanding of freedom of the press).

${ }^{216}$ See supra notes $37-46$ and accompanying text. 
When the determination depends upon full development of facts, there can be no preliminary disposition no matter who makes the decision. Many cases, though, are ultimately disposed of on the basis of judicial analysis of the publication itself. Cases are litigated for years, only to have an appellate court eventually decide that the statement itself is constitutionally incapable of supporting a libel judgment. ${ }^{217}$

Devising a way to obtain these crucial determinations without full trial of all issues is an obvious avenue of reform. What is needed is a mechanism for identifying issues that (1) are likely to be decisive, (2) can be decided independently of other issues in the case, and (3) are suitable for resolution by judges rather than juries. Procedures would have to be created to secure the trial judge's decision on these matters in advance of trial. It might or might not be desirable to provide for interlocutory appeals; to avoid expanding litigation in the attempt to simplify it, the process would have to be kept lean and restricted to truly decisive issues.

These are not easy matters to resolve, but the most perilous step has already been taken in the decision to transfer the ultimate decision from juries to judges. Defendants, who now enjoy two chances of prevailing on any independently reviewable issue, may argue that taking away one of those chances denies their right to jury trial, but the argument is untenable. If plaintiffs' rights are not violated by allowing judges to ignore jury findings after the fact, defendants' right to jury trial cannot be violated by making the same findings before trial.

\section{B. Litigation Costs}

The impact of litigation costs on media is well recognized. The chilling effect of which the media complain obviously does not come solely from the judgments they ultimately pay, since the media enjoy success rates that most other classes of tort defendants would envy. Rather, the chill comes primarily from the cost of litigating. Some of these costs, such as the loss of credibility and interference with editorial and business functions, are intangible. The major cost, however, is the expense of litigating in an area where even the most

217 See e.g., Janklow v. Newsweek, Inc., 788 F.2d 1300 (8th Cir.) (holding that defendant's statements were absolutely protected), cert. denied, 479 U.S. 883 (1986); Pring v. Penthouse Int'l, Ltd., 695 F.2d 438 (10th Cir. 1982) (holding that a fictional statement incapable of literal interpretation was protected), cert. denied, 462 U.S. 1132 (1983). 
ordinary case is likely to involve complex constitutional issues. Controlling these costs must be a target of any reform.

Less well recognized are the effects of litigation costs on defamation plaintiffs. Plaintiffs probably do not match media defendants' expenditures dollar-for-dollar, but a plaintiff must incur substantial expense to compete against a defendant who is willing to spend six- or seven-figure amounts. For high-profile public-figure plaintiffs, litigation expenses in excess of $\$ 1$ million are not unusual. ${ }^{218}$

Informed lawyers considering taking libel cases on contingent fee must look for even larger recoveries than they would require in other tort cases, because they know that libel cases, at least against media defendants, tend to be expensive and protracted, defendants are not likely to settle, and judgments are likely to be reversed on appeal. Unless their litigation decisions are utterly unconstrained by financial considerations, those few plaintiffs who pay their lawyers on an hourly basis must make some similar calculation. ${ }^{219}$

For most plaintiffs, libel litigation is economically feasible only because of the possibility of recovering presumed or punitive damages. Very few libel plaintiffs suffer enough provable pecuniary loss to justify litigating for that element of damages alone. In the physical torts, the expansiveness of damages for pain and suffering often makes it possible for plaintiffs to seek recovery for the medical expenses and lost earnings that otherwise would not be worth suing for. Damages for emotional distress do not fully serve that role in defamation because juries normally do not award them as generously as they award damages for pain and suffering.

Reforms that deny recovery for presumed and punitive damages therefore create a substantial risk of abolishing the libel action de facto. Liability can be abolished almost as effectively by making it uneconomical for plaintiffs to sue as by adopting rules denying liability. Retaining the present liability rules but restricting recovery

218 The plaintiff in Tavoulareas v. Piro, 817 F.2d 762 (D.C. Cir.) (en banc), cert. denied, 484 U.S. 870 (1987), is reported to have incurred attorneys' fees of $\$ 2$ million. See ANNENBERG PROPOSAL, supra note 5, at 9. An attorney for entertainer Wayne Newton testified that his client had incurred expenses of "well over a million dollars" by the time of trial. See Brief of Plaintiff/Appellee at $76 \mathrm{n} .89$, Newton v. NBC, 930 F.2d 662 (9th Cir. 1990) (Nos. 89-55220, 89-55285), cert. denied, 112 S. Ct. 192 (1991). The foundation that financed General William Westmoreland's suit against CBS is reported to have spent more than $\$ 3.5$ million in his behalf. See BOB BREWIN \& SYDNEY SHAW, VIETNAM ON TRIAL: WESTMORELAND VS. CBS 365 (1987).

${ }^{219}$ See supra note 67 and accompanying text. 
to actual injury would have that effect, because it would reduce the economic incentive to sue without reducing the expense of litigating. Reforms that reduce potential recovery (or replace monetary recovery with some other remedy such as declaratory judgment) must also scale down litigation costs so plaintiffs can afford to pursue the remedy.

One cannot assume that reducing the stakes will necessarily reduce litigation costs, because financial constraints do not operate symmetrically on defamation plaintiffs and media defendants. The latter are potential repeat players in the libel arena. Most are committed to a policy of aggressively contesting all libel claims. ${ }^{220}$ Their litigation decisions in a particular case may be influenced by the effects of those decisions on other potential libel plaintiffs. Spending $\$ 100,000$ successfully defending a case that could have been settled for $\$ 50,000$ may be perfectly sound economically if it deters others from suing. Likewise, a manifest willingness to spend $\$ 100,000$ to defend a suit for $\$ 50,000$ in actual injury makes sense if it persuades the plaintiff that winning will cost too much to be economically rewarding.

Even the declaratory judgment action is subject to this repeatplayer influence. Media might decide that their long-term interests require that they contest such actions with a vigor totally out of proportion to the stakes in the particular case, with the aim of discouraging future declaratory judgment plaintiffs. ${ }^{221}$ The solution is to either (1) make it possible for both sides to spend

${ }^{220}$ The following excerpt from an article about the success that supermarket tabloids enjoy in avoiding libel liability describes such a policy:

The tabloids' lawyers, employing a defense strategy that is often used by daily newspapers and other publications in libel suits, usually file a barrage of motions in court that tend to delay cases and put pressure on the plaintiffs to settle.

As a result, very few lawsuits ever come to trial. Some end with a settlement that includes a printed retraction or an agreement that the newspaper will not write anything about the celebrity for a specified period.

....

"Our strategy is to do the best possible job for our client," [a lawyer for the National Enquirer] said. "And that, of course, means litigating with all the resources necessary. We do what we need to do to win the case. We do not engage in overkill. We engage in a thorough defense of the Enquirer."

How the Supermarket Tabloids Stay Out of Court, N.Y. TIMES, Jan. 4, 1991, at B14.

${ }^{221}$ Media might also decide they can achieve about the same result far more cheaply by simply refusing to contest declaratory judgment actions, thereby depriving the judgments of any significance. 
enough to be competitive or (2) control litigation costs so neither plaintiffs nor defendants are priced out of the libel litigation market. Either is exceedingly difficult to achieve.

Providing a mechanism to shift litigation costs may create more problems than it solves. A rule awarding attorneys' fees to the prevailing party is not a satisfactory solution. Such a rule increases the stakes for both sides, when the objective should be to reduce them. If both sides have perfect information about their chances of winning, and act rationally on that information, a fee-shifting rule should have no effect on total litigation costs. But if either side overestimates its chances, it is likely to overspend, unjustifiably increasing the total cost of litigation to the detriment of the party that eventually pays the costs. The available data suggest that on the plaintiff's side, at least, lawyers' expectations of success tend to be "wildly overoptimistic."222 And defendants, for the reasons described above, may overspend in particular cases to achieve long term benefits in other cases.

A two-way fee shifting rule is unsatisfactory for the additional reason that in practice it will tend to be a one-way rule. Media defendants, as a class, are more likely to be able to pay a judgment, including a judgment for attorneys' fees, than defamation plaintiffs. Thus, prevailing plaintiffs would get a reliable source of recompense for litigation costs, while prevailing defendants would often get only an uncollectible judgment. Attempting to require the parties to give some advance assurance of ability to pay might create as many problems as it solved. For example, a rule requiring plaintiffs to post substantial bonds to assure payment of attorneys' fees might make it easier than ever for defendants to price plaintiffs out of the contest. A one-way rule, awarding attorneys fees to prevailing plaintiffs, would make it easier for deserving plaintiffs to obtain a remedy. It would create a plaintiff's libel bar, which would make the level of expertise more nearly equal on each side and thus make the system work more aesthetically and perhaps more justly. But it might also foster an unacceptable level of harassment of the media.

Limiting litigation costs is also problematic. The usual assumption is that simplifying the issues-for example, omitting any fault requirement from the declaratory judgment action-will reduce litigation costs enough to make the remedy economically feasible. No matter how streamlined the proceeding, however, it is sure to

222 See LIBEL LAW AND THE PRESS, supra note 3, at 72. 
leave the determined litigator many opportunities to make the litigation costly to the opponent. Determinations of truth or falsity, which seem to be the irreducible minimum in all the reform proposals, can sometimes be expensive undertakings. Most of the evidence in the Westmoreland case, on which both parties are said to have spent at least $\$ 7$ million, ${ }^{223}$ went to the issue of falsity. Many of the proposals impose threshold requirements, such as demands for retraction. The adequacy of the plaintiff's demand and effectiveness of the defendant's response are sure to present issues that can quickly multiply the cost of the proceeding. Moreover, no reform can assure that there will not be expensive quarrels over jurisdictional, procedural, and evidentiary points.

The reformers' dilemma is that anything that makes it financially feasible for plaintiffs to litigate elevates the stakes. This induces both sides to litigate more vigorously and expensively, diminishing the effectiveness of the remedy while increasing the chill on speech. The root of the problem is that media defendants, as a class, have the means and the incentive to spend what it takes to make sure libel does not become an effective remedy. I have little confidence that fee-shifting can solve this problem. The professional zeal and economic interest of lawyers conspire to escalate fees on both sides. A better solution is to devise remedies that cannot be thwarted by a willingness to out-litigate the opponent-a challenge that our legal system is rarely able to meet. Proposals to substitute a vindicatory remedy for monetary awards are an attempt to do this, but they cannot succeed unless they can solve the problem of financing litigation without escalating costs.

The dilemma could be solved by a system that gave defamation victims relatively easy recoveries of modest amounts of money. The liability rules would have to be simple and clear enough to make it futile for defendants to spend large sums trying to defeat them, and courts would have to police the size of awards vigilantly. Here, too, the natural proclivities of the bar would press for escalation: plaintiff's lawyers would press for higher awards and defendant's lawyers would seek new liability limitations that would create additional litigable issues. Sustained efforts to substitute modest but accessible remedies for full-blown tort litigation have been

${ }^{223}$ See Martin Tolchin, Westmoreland Urges News Media To Provide a New Libel Remedy, N.Y. TIMES, Mar. 16, 1985, at 8. This estimate may be too low; according to one source, CBS spent $\$ 5-\$ 10$ million and Westmoreland more than $\$ 3.5$ million. See BREWIN \& SHAW, supra note 218, at 354, 365. 
reasonably successful, however, in other areas (such as worker's compensation), and a similar determination might succeed in libel.

\section{Politics of Reform}

The principal interest groups affected by libel law are the media and their lawyers and insurers. Nonmedia defendants ${ }^{224}$ and plaintiffs are too randomly distributed to have a collective voice, and there is no organized plaintiffs' libel bar. Libel law reform therefore has no political constituency unless the media and their allies support it. So far they have not done so.

For all the rhetoric about the adverse effects of libel law on speech, it is entirely possible that media fear the chill of expensive litigation less than they fear the chill of more frequent accountability. The former is a known evil, while the perils of the latter can only be guessed. A declaratory judgment remedy, for example, might enmesh the media, or particular media outlets, in many minor-league lawsuits over inaccuracies that today go unchallenged. There are media antagonists, both national and local, who would happily avail themselves of new opportunities to bedevil the media they dislike. The courts might eventually find ways to deny a remedy to those who would use it to harass without withdrawing it from those who have been injured, but it is impossible to assure the media in advance that new remedies cannot be misused.

Any reform that must be accomplished one state at a time offers little comfort to the national media or even to local media whose broadcasts or publications cross state lines. Their risk assessments must take into account the least protective state law to which they may be subject. The flexibility of modern jurisdictional, venue, and choice-of-law rules often allows a plaintiff to choose a state whose law is congenial. ${ }^{225}$ The benefits of statutory reform would be fully available to the media only if adopted federally or by all the states uniformly. Constitutional protections have the considerable advantage of being applicable instantly and uniformly throughout the United States.

${ }^{224}$ Credit reporting agencies, data banks, and other information businesses are potential interest groups, but so far they have not been a significant voice.

${ }^{225}$ See Keeton v. Hustler Magazine, Inc., 465 U.S. 770, 779 (1984) (holding that the plaintiff, despite having no connection to the forum state, could maintain suit there to take advantage of that state's unique statute of limitations so long as defendant had the requisite minimum contacts). 
Moreover, media may feel they have less to gain from reform than the reformers suppose. What the reform proposals offer the media are various devices for avoiding full-scale litigation and disastrously large judgments. But the media already have some control over these risks. Many proposed reforms would allow the media to avoid all or most liability by promptly retracting. ${ }^{226}$ Although under current law retraction does not bar liability altogether, it goes a long way toward minimizing risks. Retraction will dissuade some, and perhaps most, plaintiffs from suing. ${ }^{227}$ Some states have statutes limiting recovery to pecuniary losses if the defendant retracts. These statutes give the prospective defendant the power to virtually eliminate any risk of a "megaverdict," and often make it uneconomical for the victim to sue at all. In other states, retraction is admissible in mitigation of damages, and frequently it defuses the threat of punitive damages.

Another common feature of many reform proposals is an attempt to limit damage awards, usually by denying punitive or presumed damages. But the media already have some opportunity to control losses through settlement. A cap on damages is better than the settlement option, from the media's point of view, because it also (1) controls losses in cases in which the plaintiff refuses to settle and (2) tends to lower the cost of settling by reducing the stakes. But the gain is the difference between a sure method of controlling losses and an imperfect one, not the difference between a sure method and no control at all. Offering the media a de jure or de facto limit on damages is therefore less enticing than it would be if the media had no present method of controlling losses.

An invisible but important force behind all these considerations is the fact that the risks of libel, including litigation costs, are insurable. For the most part, the risk posed by a megaverdict is not that a newspaper will be put out of business-it is a risk that next year's insurance premiums will increase. A libel suit is no greater threat to the defendant's survival than a suit by a pedestrian run over by one of the newspaper's delivery trucks and the risk is equally insurable. Libel insurance policies, unlike the policies available to many other classes of defendants, typically allow the insured to be represented by its own lawyers rather than lawyers

226 See, e.g., ANNENBerg Proposal, supra note 5, § 3(a); Proposed Defamation ACT, supra note $7, \S 6$.

227 In the Iowa study, $71 \%$ of the plaintiffs said they would have been satisfied with a correction or retraction. See LIBEL LAW AND THE PRESS, supra note 3, at 24. 
chosen by the insurance company, and libel insurers often honor their media customers' choice to fight rather than retract or settle. Thus, media often are insured against their own tactical miscalculations as well as the unavoidable risks of litigation.

Although much of the discussion about the free speech implications of libel focuses on the impact of particular cases, the more relevant focus is on aggregate costs. However threatening multi-million-dollar libel judgments may seem, the industry against which they are assessed is one of the largest and most lucrative in the country. ${ }^{228}$ To the extent that libel risks are insurable, they do not threaten free speech interests unless the aggregate costs are so great that insurance becomes unavailable or too costly for some media outlets. The insurance system is imperfect, of course; some media fail to secure coverage, some are underinsured, and a few perhaps cannot obtain coverage. But insurance is available far more often than not, and its existence diminishes media zeal for libel law reform.

The libel insurers themselves are not a constituency for reform. Several of the companies are closely allied with the media industries and are therefore unlikely to support proposals their clients oppose. For independent insurers, any program to reduce risks, and therefore premiums, works against the insurer's ultimate interest in maximizing the volume of premium revenues available for investment.

It is easy to overestimate the benefit to media of reforms that substitute declaratory relief for monetary judgments. Losing a libel case costs a media defendant more than money. An image of credibility is to a news organization what an image of fiscal responsibility is to a financial institution. Losing a libel case, even when no damages are awarded, tarnishes that image. Understandably, media will assign some value to this consideration in deciding how much they gain from the substitution of remedies. They should also take into account, however, the extent to which their credibility is undermined-and the public's goodwill eroded-when they prevail under the present system on an issue like want of actual malice. Such a victory may not strike the public as a "fair" win on the merits.

${ }^{228}$ The communications industry is said to account for $6 \%$ of the gross national product. See Richard Harwood, Multiple Media Inc., WASH. PosT, Mar. 17, 1991, at D6. 
The present law, for all its shortcomings, gives media considerable control over the risks they fear most: high litigation costs and windfall verdicts. Reform offers uncertain benefits and guaranteed uncertainty. One indisputable lesson of the past twenty-five years is that changes in libel law rarely have the effect they were expected to have. Dean Prosser thought New York Times v. Sullivan was a death knell for the libel cause of action. ${ }^{229}$ Justice White thought the fault requirement of Gertz would render defamation victims "powerless to protect themselves." 230 In hindsight, both obviously misjudged the impact of those cases. Media skepticism of reform proposals is understandable. They are being asked to trade risks that are generally known, sometimes controllable, and nearly always insurable, for changes whose effects are at least as unpredictable now as the effects of New York Times and Gertz were when those cases were decided.

In short, there is no political constituency for reform. The media are largely uninterested, their lawyers are hostile, and plaintiffs are too diffuse to have an effective political voice. Independent law reform entities such as the American Law Institute and the National Conference of Commissioners on Uniform State Laws have continuity and credibility, but whether legislators will embrace their recommendations in the absence of any political impetus is questionable.

State courts, the usual source of change in tort law, are dissuaded from reforming the law of libel by the Supreme Court's de facto preemption of the subject. Theoretically, of course, the scheme devised by the Supreme Court to protect speech from the threat of libel actions is not preemptive; states are free to enforce any other scheme sufficiently protective of speech. The statement that "private plaintiffs may recover for actual injury without showing actual malice" does not state a rule of law, but merely the scope of the constitutional limitation. ${ }^{231}$ States may (and some do) require private plaintiffs to show actual malice. ${ }^{232}$ Likewise, they may

229 See WILLIAM L. PROSSER, HANDBOOK OF THE LAW OF TORTS 819 (4th ed. 1971). ${ }^{230}$ Gertz v. Robert Welch, Inc., 418 U.S. 323, 370 (1974) (White, J., dissenting). 231 Id. at 347.

232 See, e.g., Sisler v. Gannett Co., 516 A.2d 1083, 1095 (N.J. 1986) (holding that a private plaintiff whose activities create risk of publicity must show actual malice); cf. Chapadeau v. Utica Observer-Dispatch, Inc., 341 N.E.2d 569, 571 (N.Y. 1975) (holding that private plaintiff must show that the publisher acted in a "grossly irresponsible manner" if the content of the publication was within the sphere of legitimate public concern). 
(and sometimes do) deny punitive damages even to plaintiffs who do show actual malice, ${ }^{233}$ or impose the limitations of Gertz on all private plaintiffs, including those defamed in purely private speech. ${ }^{234}$ State law still controls a great many issues, including what is defamatory, what effect retraction has, what injuries are compensabie, and what privileges are applicable. The states therefore retain considerable power to change the law of libel. But the dynamics of litigation do not facilitate innovation, at least when the Supreme Court does not encourage it. Once the Supreme Court prescribes a route that will survive constitutional scrutiny, litigants do not pursue other paths. And when the litigants do not advance alternatives, state courts do not embrace them.

Without some help from the Supreme Court, the reform movement is doomed. The National Conference of Commissioners on Uniform Laws and other reformers are trapped between constitutional constraints on one side and lack of a political constituency on the other. Both of these obstacles make it unrealistic to look to legislators for the thorough rethinking that libel law needs.

\section{CONCLUSION}

The present law of libel is a failure. It denies most defamation victims any remedy, and at the same time chills speech by encouraging high litigation costs and occasional large judgments. The route to reform is obvious: provide a remedy that will simplify litigation and reduce the threat of windfall verdicts. That route, however, is a perilous one, fraught with political difficulty, empirical uncertainties, and dangers for freedom of speech. Deciding whether libel law is worth reforming requires a collective decision about the value we want to place on reputation as we enter the twenty-first century.

As a social value, reputation has been one of the casualties of the twentieth century. In 1942, at the dawn of his brilliant career, David Riesman identified reputation as an essentially precapitalist

${ }^{233}$ See, e.g., Stone v. Essex County Newspapers, 330 N.E.2d 161, 169 (Mass. 1975) (refusing to allow punitive damages in defamation actions); Wheeler v. Green, 593 P.2d 777, 789 (Or. 1979) (holding that the Oregon Constitution prohibits punitive damage awards in defamation cases).

${ }^{234}$ See, e.g., New England Tractor-Trailer Training v. Globe Newspaper Co., 480 N.E.2d 1005, 1009 n.4 (Mass. 1985) ("We view the fault requirement of Gertz to be intact regardless whether the private parties are suing on matters of public or private concern."). 
value more suited to Europe than America. "[W]here tradition is capitalistic rather than feudalistic, reputation is only an asset, 'good will,' not an attribute to be sought after for its intrinsic value. And in the United States these business attitudes have colored social relations. The law of libel is consequently unimportant." ${ }^{235}$ That may or may not have been true fifty years ago, but it is certainly a fair description of the law's treatment of reputation today.

A world in which reputation is not a legally protected interest is no longer inconceivable. Recent experience demonstrates that victims of defamation survive and sometimes even prosper without benefit of legal remedy. The public has learned to adjust its perceptions of the media to take into account the extremely complex relationship between truth and defamation that the present law creates; a system in which the law exerted no influence on these matters would be far easier to take into account. Political life and public discourse have adapted to the virtual abandonment of libel and would no doubt survive its actual demise.

Abolishing libel law is the only step that will eliminate the chill it imposes on speech. No reform can provide a remedy for defamation that imposes no burden on speech. Reformers must admit they are willing to burden speech, and media partisans who argue that any chilling effect is unconstitutional must admit they are urging the abolition of libel. The very purpose of libel, and this includes any remedy for harm to reputation, is to chill speech. If there is no speech that deserves to be chilled, there should be no law of libel. Reasonable people can and do hold that view. Others believe damage to reputation is too elusive or evanescent to justify the chill that libel law produces. Still others believe the marketplace should indeed be the only arbiter of truth.

Though I appreciate the force of those views, I do not share them. A world without libel law is not unthinkable, but it would be a less civil world, a less just world for victims of defamation, a world less anchored to truth and reason. The civilizing influence of libel law is valuable enough to justify the price it exacts from speech. Libel law is worth reforming, but only if the result offers real protection for the values of truth and reputation commensurate with its inevitable burdens on speech.

235 David Riesman, Democracy and Defamation: Control of Group Libel, 42 CoLUM. L. REv. 727, 730 (1942). 
Only the Supreme Court can instigate this reform. The system of libel law the Court has created so permeates the field that other agencies of reform are effectively disabled. The system protects media imperfectly, but enough to keep them from espousing serious reforms. It allows a plaintiff to recover occasionally, forestalling the public clamor that might arise if recovery were barred altogether. There is no political constituency for statutory reform, and little room within present constitutional constraints for innovation by state courts. The Gourt must undertake libel law reform itself, at least to the extent of re-empowering other instigators of change.

Prescribing the reforms is beyond the compass of this Article, but the principal strategic options are obvious. One is retrenchment. The Court might simply give up some of the territory it has occupied-by abandoning the actual malice rule, for example. Just as the Court's intervention has driven other players out of the process of revising libel law, so might its retrenchment draw them back. A drastic retrenchment would no doubt make the media more receptive to legislative reforms. That would impose high (though perhaps temporary) costs on speech, however, and the Court is unlikely to abdicate its historic First Amendment role on no more than the hope that other players will step forward to provide satisfactory substitutes.

A second strategy might be to invite proposals for reform. Without abandoning the present constitutional scheme, the Court could announce its willingness to consider alternative accommodations between speech and reputational interests. Such an invitation would free the proponents of legislative reform from the constitutional straitjacket in which they now operate. The uncertainty it would create might make the media more tractable participants in the reform discussions. Such an invitation might also stimulate advocates, trial judges, and state appellate courts to propose their own alternatives, thereby restoring the state courts to their traditional role as the principal innovators in the law of defamation. State courts are not oblivious to the interests of the media, and today many are at least as sensitive as the present Supreme Court to free speech concerns. In recent years, some state courts have been creative in their solutions to other types of free speech problems. ${ }^{236}$

${ }^{236}$ See, e.g., Chapadeau v. Utica Observer-Dispatch, Inc., 341 N.E.2d 569, 571 (N.Y. 1975) (creating "gross irresponsibility" fault standard for private-plaintiff libel cases); Renwick v. News and Observer Publishing Co., 312 S.E.2d 405, 411 (N.C. 1984) 
This strategy has the advantage of leaving the Court in its familiar reactive role, acting as final arbiter rather than innovator. But that is also its disadvantage. The strategy assumes that legislators, litigants, and judges will be willing to devise solutions they know the Supreme Court may disapprove. It may be difficult for advocates to persuade their clients to advance, and trial judges to espouse, untried and as yet unapproved theories as long as tried and approved routes are still available. The invitation strategy is better suited to a field the Court has only begun to occupy than to one it dominates.

More importantly, even if this strategy were to succeed in generating acceptable alternatives to the present constitutional law of libel, its result after many years of effort would probably be a patchwork of differing liability schemes. Eventually a single scheme might evolve, either because the states all agreed on its superiority or, more plausibly, because only one received Supreme Court approval. But unless and until that happened, media and other potential defendants would be subject to even more variations in libel law than they are now. Libel is a field that cries out for some uniformity. Today intrastate speech is even rarer than intrastate commerce. Defamers are rarely subject to only one state's law, and unless they are, they must tailor their speech to the least protective state law to which they may be subject. We should not forget that it was Alabama's eagerness to punish the New York Times and other out-of-state media that drew the Supreme Court into libel law in the first place. ${ }^{237}$ A system in which an interstate speaker might face declaratory judgment actions without fault defenses in one jurisdiction, negligence-based actions for limited damages in another, and unlimited damages upon a showing of actual malice in another, would multiply the already considerable difficulty in assessing risks. Non-uniformity exacerbates the chill of libel law, and a strategy that encourages it is unsatisfactory.

A third strategy-more radical but also more effective-would make the Supreme Court itself the principal reformer of libel law. The Court would prescribe new accommodations of speech and

(rejecting false-light theory of recovery in invasion of privacy action); State v. Henry, 732 P.2d 9, 17 (Or. 1987) (interpreting Oregon Constitution to protect sale of obscenity to consenting adults); Anderson v. Fisher Broadcasting Cos., 712 P.2d 803, 814 (Or. 1986) (redefining the private-facts branch of invasion of privacy).

237 See Lewis, New York Times v. Sullivan Reconsidered, supra note 3, at 604-07 (describing the reaction of public officials in Montgomery, Alabama to the advertisement in the New York Times that became the subject of New York Times v. Sullivan). 
reputational interests as a matter of constitutional law. It might decree, for example, that the Constitution requires no showing of fault if the remedy sought is only a declaration of falsity. It might announce new limitations on damages, with corresponding reductions in plaintiffs' burdens. The Court might devise a more sophisticated accommodation, one that addresses the dynamics and costs of libel litigation as well as questions of fault and remedies. It might explicitly authorize trial judges to decide at the outset whether the challenged statement was sufficiently factual, harmful, and remote from truth to be justifiably burdened by further litigation. Acknowledging that effective protection of speech requires a diminished role for juries, it might authorize even more aggressive use of summary judgment and judicial review. The Court might even take the assessment of damages out of the jury's hands.

Comprehensive law reform is not a familiar task for the Supreme Court. It is not accustomed to reviewing systems of law rather than specific rules. Case-by-case adjudication of specific constitutional issues does not invite advocacy on the redesign of an entire branch of tort law. Those are weighty objections, but they come too late. Over the past quarter century, case by case and bit by bit, the Court has thoroughly revised the common law of libel. It has created not merely a few constitutional limitations on state tort rules, but a matrix of substantive principles, evidentiary rules, and de facto innovations in judge-jury roles and other procedural matters. These are all constitutionally based and can only be changed by those who have the power to change constitutional rules. Having created the system that is the source of so much dissatisfaction, the Court cannot now demur on the ground that law reform is not its business. 